BIS WORKING PAPERS

No. 61 - November 1998

\title{
FOREIGN DIRECT INVESTMENT AND EMPLOYMENT IN THE INDUSTRIAL COUNTRIES
}

by

P. S. Andersen and P. Hainaut

BANK FOR INTERNATIONAL SETTLEMENTS

Monetary and Economic Department

Basle, Switzerland 
BIS Working Papers are written by members of the Monetary and Economic Department of the Bank for International Settlements, and from time to time by other economists, and are published by the Bank. The papers are on subjects of topical interest and are technical in character. The views expressed in them are those of their authors and not necessarily the views of the BIS.

Copies of publications are available from:

Bank for International Settlements

Information, Press \& Library Services

CH-4002 Basle, Switzerland

Fax: +41 61/2809100 and +4161/2808100

This publication is available on the BIS website at www.bis.org.

(C) Bank for International Settlements 1998.

All rights reserved. Brief excerpts may be reproduced or translated provided the source is stated. 
BIS WORKING PAPERS

No. 61 - November 1998

\title{
FOREIGN DIRECT INVESTMENT AND EMPLOYMENT IN THE INDUSTRIAL COUNTRIES
}

\author{
by \\ P. S. Andersen and P. Hainaut *
}

\begin{abstract}
Since the trough in 1982, the growth of real foreign direct investment (FDI) outflows and inflows for the OECD countries has been very high, far outpacing that of foreign trade and real GDP. While such flows are likely to have increased the efficiency with which global capital is being used, they have also led to concerns that outflows from the industrial countries serve as an instrument for exporting jobs to low-wage countries. The purpose of this paper is to look for evidence regarding the precise relationship between FDI outflows and employment in the source countries. The empirical evidence mostly relies on estimated relationships between FDI flows and various components of demand but is derived from time-series analyses for individual countries as well as from panel regressions. All in all, we find only limited evidence that FDI outflows lead to job losses in the source countries. While it is true that domestic investment tends to decline in response to FDI outflows, emerging market economies receive only a small, albeit growing, share of global outflows. It also appears that high labour costs encourage outflows and that exchange rate movements may exacerbate such effects. However, the principal determinants of FDI flows are prior trade patterns, IT-related investments and the scope for cross-border mergers and acquisitions. Moreover, there is clear evidence that, by improving distribution and sales channels, FDI outflows complement rather than substitute for exports and thus help protect rather than destroy jobs in the source countries.
\end{abstract}

* Without implication we acknowledge comments on an earlier draft by R. Lipsey and participants in seminars at York University, the Deutsche Bundesbank and the Bank of Canada. We would also like to thank S. Arthur for overseeing the publication and L. Morandini for expert secretarial assistance well beyond her call of duty. 



\section{Contents}

Introduction

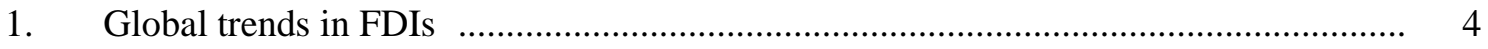

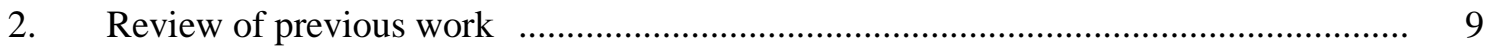

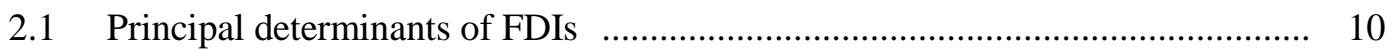

2.2 Direct linkages between foreign and domestic employment f.......................... 14

2.3 Indirect linkages between foreign and domestic employment $\ldots \ldots \ldots \ldots \ldots \ldots \ldots \ldots \ldots \ldots . . . . . . . . .17$

3. Empirical estimates of FDI inflows and outflows …............................................. 21

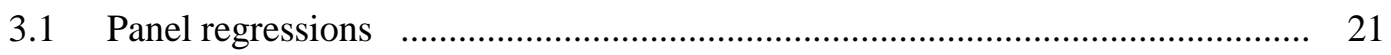

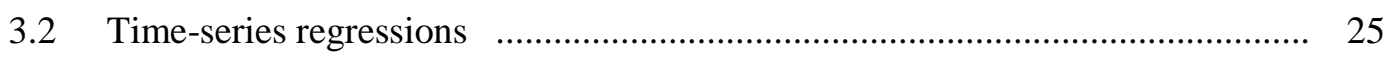

4. Effects of FDIs on domestic investment and net exports f........................................ 26

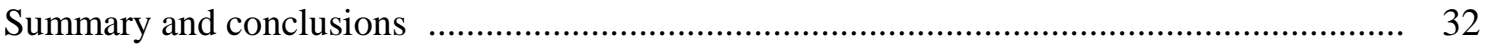

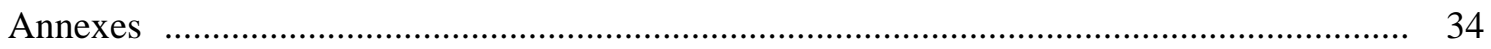

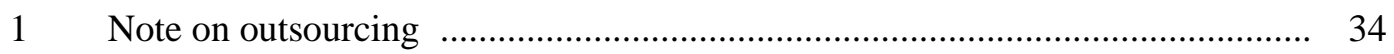

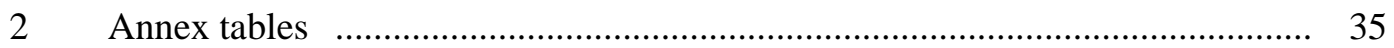

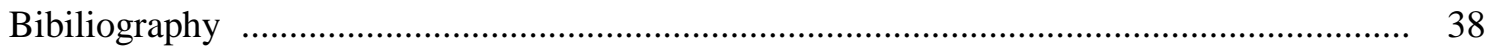





\section{Introduction}

"We are living in an era where foreign investment is more important than foreign trade."

Korean president-elect Kim Da-jung in warning workers about the risk of job losses as a result of industrial restructuring. Financial Times, 27th December 1997.

“In 1997, almost half the company's [Milacron] sales of nearly $\$ 2$ bn came from outside the US, up from just one-third in 1990, while over this period the proportion of employees based outside the US has risen from 20\% to 40\%”, Financial Times, 13th January 1998.

"For us, it is really the access to lower labour rates and to be able to get our products back to our US customer base in one or two days."

Douglas Shield, Noma chief financial officer on the growth of Canadian firms setting up plants in the Mexican maquiladora zone. The Globe and Mail, 8th July 1998.

One feature of the growing integration of the world economy has been the marked rise in foreign direct investment (FDI). Since the trough in 1982, the growth of real FDI outflows and inflows $^{1}$ for the OECD countries has been very high, far outpacing that of foreign trade and real GDP (Graph 1 and Table 1). Moreover, sales of foreign-owned affiliates exceed "arm's-length" exports and imports, and intra-firm sales account for a rising proportion of world trade. Other measures, to be discussed below, corroborate the impression that multinational enterprises (MNEs) play a major, if not dominating, role in the world economy and that their increasing influence calls for a revision of traditional concepts and measures of world trade.

Table 1

\section{Comparative trends of foreign direct investment in OECD countries}

Annual percentage changes, in constant prices*

\begin{tabular}{|l|c|c|c|c|c|c|c|}
\hline & GDP & Exports & $\begin{array}{c}\text { Gross fixed } \\
\text { investment }\end{array}$ & Outflows & Inflows & $\begin{array}{c}\text { Outward } \\
\text { stocks }\end{array}$ & $\begin{array}{c}\text { Inward } \\
\text { stocks }\end{array}$ \\
\hline $1981-89$ & 3.0 & 4.5 & 3.4 & 14.1 & 12.7 & 11.9 & 14.2 \\
$1990-96$ & 1.9 & 5.5 & 2.0 & 0.6 & -1.7 & 12.5 & 10.8 \\
\hline
\end{tabular}

* Except for outward and inward stocks (current prices and exchange rates).

Sources: IMF Balance of Payments Statistics, OECD National Accounts, OECD International Direct Investment Statistics and UN World Investment Report.

1 The figures used above and in Graph 1 below were derived by deflating flows in US\$ by the deflator for OECD GDP in US\$. However, as discussed in UNCTAD (1997), defining and finding an appropriate deflator for FDI flows is not a straightforward exercise. 


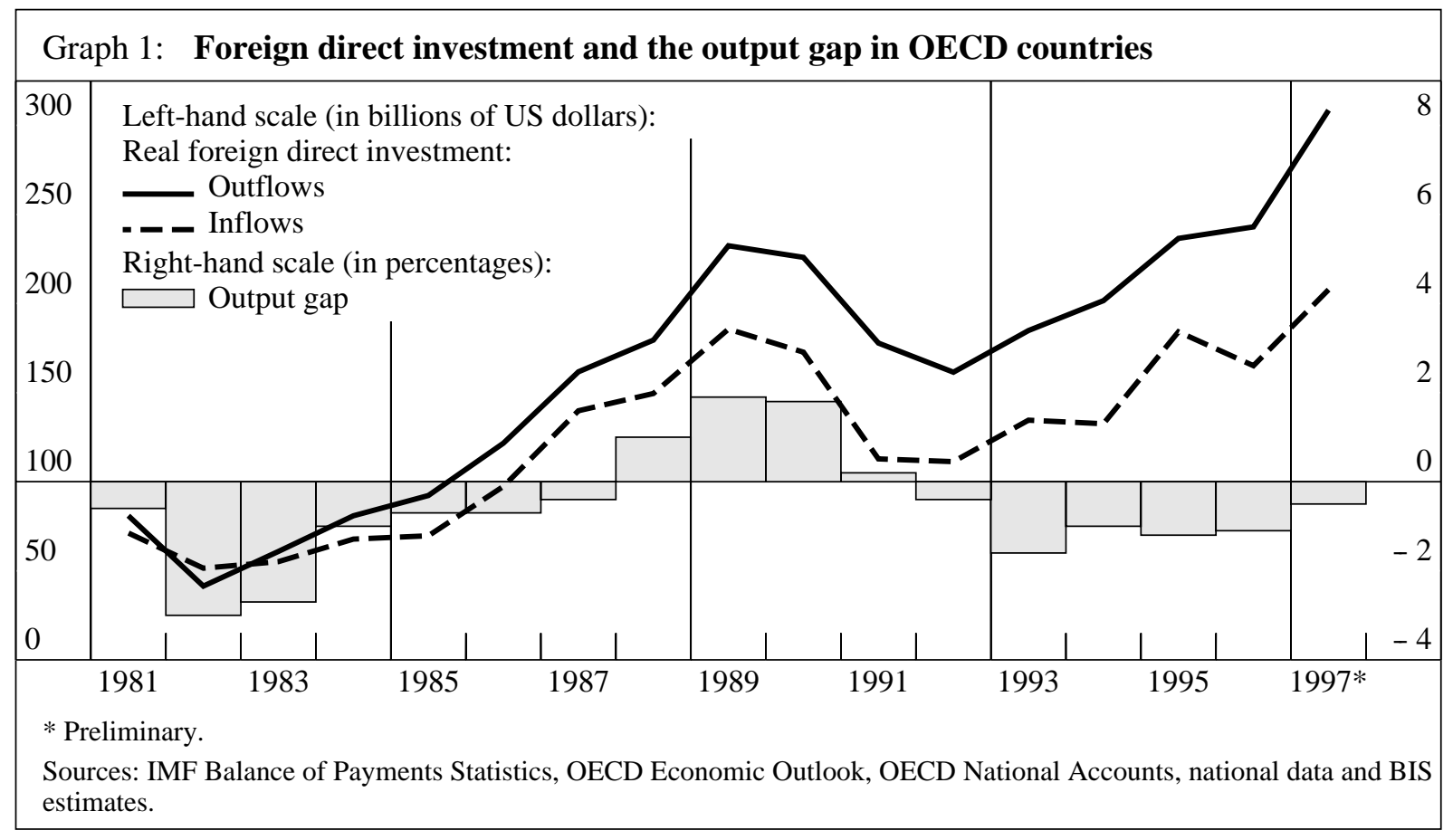

The impressive rise in cross-border capital flows is likely to have increased the efficiency with which global capital is being used and provided a stimulus to productivity and real income growth. Nonetheless, the activities of MNEs and the internationalisation of their production via FDIs have often met with concerns among policy-makers and, in particular, trade unions. For many years, a number of countries resisted inflows, fearing that the foreign companies might outcompete domestic firms and increase concentration. Similarly, some interpret the rising share of foreign affiliates in foreign trade as evidence that outflows from the developed countries serve as an instrument for exporting jobs to low-wage countries; or, even if total employment does not change, for causing major shifts in the relative demand for skilled and unskilled workers. ${ }^{2}$ Others argue that such views implicitly assume that output is fixed. Instead, outflows and the increasing importance of foreign affiliates reflect an attempt by MNEs to increase total output or their market shares. Moreover, as the last of the above quotes suggests, there are factors other than low labour costs which motivate investment abroad.

The initial purpose of this paper was to look for evidence regarding the precise relationship between FDIs and employment in the industrial countries, using time-series and crosscountry analyses on corresponding data for FDIs, affiliate production and employment in source countries and host countries respectively. However, because only few countries provide sufficiently

2 In many respects, the issue of whether FDI affects wage structures and employment parallels the discussion of whether imports from low-wage countries adversely affect workers with lower skills. For reasons of space we shall largely disregard this discussion except to note that the alleged adverse effects of foreign trade are exclusively attributed to imports while for FDIs both outflows and inflows have been subject to criticism. Except for a brief discussion in Annex 1, we also ignore another related issue; viz. the impact of outsourcing on home-country employment and wages. 
long data series on employment abroad and even fewer have series on jobs created by investment inflows, this project was not feasible. Another potential problem is that data on affiliate production are equally sparce and flows and stocks of FDIs, which are essentially financial variables, might not be very reliable indicators of affiliate production. ${ }^{3}$ However, using US data, it appears that this is not a major problem. As Table 2 shows, the distribution of output by US affiliates across 35 countries is closely correlated with the distribution of outward stocks; indeed, when using a linear instead of a loglinear specification, it appears that the correspondence is even higher than for capital stocks; which, in theory, is a better measure of plant size and capital inputs.

Table 2

Gross output, outward stocks and total assets

Cross-country regressions, US affiliates, 35 countries

\begin{tabular}{|l|l|l|l|c|}
\hline \multirow{2}{*}{$\begin{array}{l}\text { Dependent } \\
\text { variable }\end{array}$} & \multicolumn{2}{|c|}{ Linear specification } & \multicolumn{2}{c|}{ Log-linear specification } \\
\cline { 2 - 5 } & $O S$ & $C S$ & $O S$ & $C S$ \\
\hline$G Y$ & $0.58^{*}$ & $0.12^{*}$ & $0.86^{*}$ & $0.84^{*}$ \\
$\mathrm{R}^{2}$ (standard error) & $0.96(2.7)$ & $0.74(7.5)$ & $0.85(0.5)$ & $0.85(0.5)$ \\
$C S$ & $4.40^{*}$ & - & $1.24^{*}$ & - \\
$\mathrm{R}^{2}$ (standard error) & $0.91(30.6)$ & - & $0.96(0.3)$ & - \\
\hline
\end{tabular}

Notation: $G Y=$ gross output, $O S=$ outward stocks, and $C S=$ total assets or capital stocks controlled by US-owned foreign affiliates. $*=$ significant at $99 \%$ level of confidence.

Even so, owing to the lack of employment data we were forced to adopt an indirect approach. Thus, in the Section 1 we compare recent trends in outflows and inflows with developments before the First World War, when the degree of globalisation was also very high, to see whether changes in distribution and in the underlying motives of FDIs provide any information on potential employment effects for source and host countries.

Section 2 further analyses the underlying motives and determinants by reviewing the literature on firms' decisions with respect to location. We also survey earlier works on the various indirect channels by which FDI can influence domestic output and employment, in particular investment, exports and imports. Section 3 attempts to quantify the determinants mentioned in the literature. We first estimate FDI equations from panel data for 21 OECD countries over the period 1981-95 and then supplement these results with time-series estimates for four of the major countries.

3 As noted by Graham (1995), FDI is really a misnomer as it refers to financial flows which may or may not be associated with investment in real assets. For instance, when a firm in country A takes over a firm in country B, the transaction is recorded as a foreign direct investment in that year, even though it is merely a change of ownership. In contrast, if the new affiliate acquires additional fixed assets in the following year but finances the purchase by credit obtained in country B, this transaction has no effect on measured outflows. 
Section 4 presents additional time-series estimates for the same four countries. More specifically, within an error correction framework, it is tested whether outflows and inflows have had any indirect effects on employment by influencing domestic investment, exports and imports. The final section summarises the empirical evidence, derives some policy implications and, in particular, points to areas in need of further research. ${ }^{4}$

\section{Global trends in FDIs}

To highlight some of the driving forces behind recent developments in globalisation in general and FDIs in particular, it is useful to take a longer perspective. While the growth of trade and FDIs has been impressive, developments over the last 15 years merely return the degree of globalisation to that existing before 1914 and, in some respects, not even that ${ }^{5}$ For instance, at its peak in 1990, when investment outflows from Japan accounted for almost 25\% of total OECD outflows, they were only $5 \%$ of domestic investment in Japan. In contrast, during the first decade of this century when global flows were dominated by the United Kingdom, outflows were almost as large as domestic UK investment and outward stocks, as a ratio to GDP, were twice as large as in 1996. Moreover, while US outflows reached an absolute peak last year, measured in relation to domestic investment and GDP they were much higher in the late 1970s (Lipsey (1994)).

Moreover, even though the growth of FDI flows has been very high over the last 15 years, it has not been very stable (Table 1). In fact, most of the expansion took place during 1981-89 while over the next seven years outflows grew by less than $1 \%$ per year and inflows declined. In

4 However, further research and more robust results may have to await the availability of comparable data as there are large discrepancies between the flows and stocks reported by home and host countries. For example, as the table below shows, Germany seems to underreport inflows, notably from the United States, while Japan underreports inward stocks (see also Jost (1997)). One reason for the discrepancy between US and German flow figures is that the latter do not include shortterm debt flows. In contrast, short-term debts are included in German stock data.

Accumulated bilateral flows and stocks

In billions of US dollars

\begin{tabular}{|l|c|c|c|l|l|l|c|}
\hline & \multicolumn{3}{|c|}{ Cumulated flows (1985-95) } & \multirow{2}{*}{ Stocks (1994 or 1995) } \\
\cline { 2 - 8 } & United States & Japan & Germany & & & \multicolumn{3}{c|}{ United States } & Japan & Germany \\
\hline United States & - & 10.4 & 19.4 & United States & - & 39.2 & 43.0 \\
Japan & 12.7 & - & 7.4 & Japan & 13.8 & - & 8.1 \\
Germany & -0.1 & 4.3 & - & Germany & 48.8 & 10.8 & - \\
\hline
\end{tabular}

Note: Figures below the diagonal indicate cumulated bilateral inflows or inward stocks reported by host countries while figures above the diagonal indicate the corresponding outflows and outward stocks reported by home countries.

Source: OECD International Direct Investment Statistics.

5 In this context, it is also worth noting that despite the rise in FDIs and in net external profits and interest payments, the ratio of GNP to GDP is for most OECD countries close to unity. The main exception is Ireland, for which GNP amounts to only $86 \%$ of GDP. 
addition, the resumption of FDI flows recorded last years (Graph 1) might be only transitory as it was led by the United States and, to a large extent, reflected the record level of mergers and acquisitions induced by the worldwide boom in equity markets. Indeed, as shown in Table 3, a 10\% rise in actual relative to trend GDP increases FDI flows by about $1 \frac{112 \% .}{6}$ Financial asset prices also affect FDIs although it is difficult to identify the precise source of this influence because interest rates and equity prices tend to be correlated $\left(\mathrm{R}^{2}=0.89\right.$ for the sample period).$^{7}$ Moreover, since mergers and acquisitions both account for a large proportion of total outflows and boost equity prices, the influence attributed to equity prices might be overstated.

Table 3

Global inflows and outflows: preliminary estimates*

1981-96, annual data

\begin{tabular}{|l|c|c|c|c|c|c|c|c|}
\hline & Intercept & Gap & Yen & Int. rate & Equities & $\mathbf{R}^{2}$ & DW & Std er. \\
\hline Inflows & $8.1(5.7)$ & $0.14(6.0)$ & $0.90(4.5)$ & $-0.25(1.1)$ & - & 0.94 & 1.98 & 0.11 \\
Outflows & $6.2(15.3)$ & $0.16(9.8)$ & $0.60(2.9)$ & - & $0.52(4.5)$ & 0.98 & 2.59 & 0.07 \\
Outflows & $10.2(8.2)$ & $0.16(7.8)$ & $0.76(4.2)$ & $-0.82(4.0)$ & - & 0.97 & 2.48 & 0.10 \\
\hline
\end{tabular}

* Coefficients obtained by regressing the following equation:

$\log$ in(out)flows $=\alpha+\beta$ Gap $+\delta \log$ Yen $_{-1}+\gamma \log$ Equities $+\eta \log$ Int. rate

where Gap $=\log$ ratio of actual to trend GDP for the OECD area; Yen = index of nominal effective exchange rate of the yen, Equities = index of US equity prices, and Int. rate = long-term US bond rate. Inflows and outflows are measured in real terms, t-statistics are given in brackets and Std er. indicates standard errors.

Yet, in some respects international integration and FDI activities are more important today than before the First World War. First, FDIs involve more countries. Although flows and stocks are still dominated by the industrial countries, the role of emerging market countries has recently grown. By the end of 1996, these countries accounted for about $30 \%$ of inward stocks (Table 4) and even though they hold less than $10 \%$ of outward stocks, the fact that their share of outflows has been close to $14 \%$ during the 1990 s indicate that they are also becoming increasingly active as source countries. However, the current financial crisis in Asia is likely to slow, at least temporarily, this process as several projects have been cancelled or postponed. On the other hand, inflows seem to have slowed only little in 1997 and might strengthen this year, given the fall in equity prices and exchange rates and the deregulations of FDI inflows in the Asian countries most affected by the crisis.

6 One source of the procyclical behaviour is the fact that reinvestment of retained profits, on average, constitutes about one-third of measured FDI flows. There are, however, large variations across countries, reflecting differences in the tax rates applying to retained earnings. For instance, in the United States, the share exceeds $40 \%$ in most years while in both France and Germany it is less than $10 \%$.

7 The negative influence of long-term interest rates on outflows shown in Table 3 could reflect the fact that higher borrowing rates in the home country encourage firms to finance real investment abroad by increasing debt in the host country. For instance (Graham op cit), real investment by US-owned affiliates actually increased sharply during the early 1980s. However, because it was mainly financed by host-country borrowing, outflows declined sharply. 
Table 4

Structural features of foreign direct investment

Ratios, in percentages

\begin{tabular}{|c|c|c|c|c|c|c|c|c|c|c|c|}
\hline & \multicolumn{4}{|c|}{ Outward stocks } & Outflows/ & \multicolumn{4}{|c|}{ Inward stocks } & Inflows/ \\
\cline { 2 - 10 } & $\begin{array}{c}\text { Stocks/ } \\
\text { GDP }\end{array}$ & $\begin{array}{c}\text { US/ } \\
\text { OECD }\end{array}$ & $\begin{array}{c}\text { Japan/ } \\
\text { total }\end{array}$ & $\begin{array}{c}\text { EU/ } \\
\text { OECD }\end{array}$ & $\begin{array}{c}\text { OECD/ } \\
\text { world }\end{array}$ & $\begin{array}{c}\text { gross fixed } \\
\text { investment }\end{array}$ & $\begin{array}{c}\text { Stocks/ } \\
\text { GDP }\end{array}$ & $\begin{array}{c}\text { US/ } \\
\text { OECD }\end{array}$ & $\begin{array}{c}\text { EU/ } \\
\text { OECD }\end{array}$ & $\begin{array}{c}\text { OECD/ } \\
\text { world }\end{array}$ & $\begin{array}{c}\text { gross fixed } \\
\text { investment }\end{array}$ \\
\hline 1980 & 6.2 & 43.4 & 3.7 & 42.0 & 97.8 & 2.6 & 4.6 & 22.3 & 49.6 & 77.8 & 2.2 \\
1990 & 9.6 & 26.9 & 12.7 & 48.2 & 93.6 & 5.9 & 8.1 & 28.8 & 51.9 & 79.4 & 4.6 \\
1996 & 12.8 & 27.4 & 11.4 & 48.6 & 91.0 & 6.3 & 10.1 & 28.4 & 53.7 & 70.2 & 4.5 \\
\hline
\end{tabular}

Sources: See Table 1.

Second, within the group of industrial countries relative positions have also changed. While the United States had a dominating position with respect to outflows and outward stocks by the end of the 1970s, the 1980s was the decade of outflows from Japan. From less than 4\%, Japan's share of total outward stocks rose to almost $13 \%$, while that of the United States declined substantially. A driving factor behind this change was the steep appreciation of the yen during the second half of the decade. Indeed, according to the estimates in Table 3, more than $30 \%$ of the rise in outflows during 1985-89 can be attributed to the effective appreciation of the yen. The asset price boom in Japan probably also played a role as it substantially increased the funds available to Japanese enterprises and, allied with the stronger yen, made foreign equities look relatively cheap.

In contrast, the appreciation of the US\$ during the first half of the decade did not lead to higher US outflows. Owing to the 1982-83 recession and the high cyclical sensitivity of FDIs, US outflows fell steeply during the early part of the period and, as discussed above, high US interest rates meant that capital expansions by US affiliates abroad were mainly financed by host-country credit. Moreover (Lipsey (1994)), the late 1970s seem to have marked a turning point with respect to the role of manufacturing and, in particular that of US multinationals. Because manufacturing is far more international than other sectors in terms of both trade and foreign direct investment, its progressively declining role in the US economy and the fact that this process started earlier than in most other countries imparted a downward trend to US outflows.

Another change among the industrial countries has been the marked increase in the share of EU countries in both inward and outward stocks. The rise accelerated after the adoption of the Single European Act in 1986 and was not only driven by growing inflows from non-member countries but also by larger inflows and outflows within the EU, even though the removal of trade barriers had been expected to reduce such flows. ${ }^{8}$

8 Owing to trade diversion and trade creation effects, the a priori impact of regional trade agreements on FDIs is ambiguous. In the case of the EU countries, the positive effects, which is confirmed in numerous other studies (see below), may, in part, be attributable to the simultaneous liberalisation of capital flows. Thus, for several countries, the rise in FDIs went hand in hand with a shift from equity to intra-firm debt financing. 
Table 5

Sectoral distribution of outward stocks

In percentages of total stocks

\begin{tabular}{|l|cc|cc|cc|cc|}
\hline \multirow{2}{*}{} & \multicolumn{2}{|c|}{ United States } & \multicolumn{2}{c|}{ Japan } & \multicolumn{2}{c|}{ Germany } & \multicolumn{2}{c|}{ United Kingdom } \\
\cline { 2 - 9 } & 1985 & 1995 & 1985 & 1994 & 1985 & 1995 & 1987 & 1995 \\
\hline Secondary & 41.1 & 36.2 & 28.8 & 27.8 & 60.5 & 31.0 & 36.0 & 43.8 \\
Tertiary & 31.5 & 52.7 & 51.7 & 65.5 & 30.5 & 67.8 & 40.0 & 40.1 \\
$\quad$ Finance & 16.9 & 33.8 & 12.6 & 18.9 & 9.8 & 24.7 & 14.0 & 15.7 \\
\hline
\end{tabular}

Source: OECD International Direct Investment Statistics.

Third, FDIs involve more sectors as the earlier dominating role of the primary and secondary sectors has diminished and the tertiary sectors are gaining ground (Table 5). The shift is most pronounced for US and German enterprises which seem to have used outflows to maintain world output and export shares by setting up marketing and sales offices abroad to improve the distribution of goods produced at home. ${ }^{9}$ The rise observed for UK outward industrial stocks mostly reflects lower investment in the primary sectors while the share of service sector investment has been surprisingly stable. In the case of Japan, the creation of transplant production facilities, notably in other Asian countries, has helped stabilise the share of industry. At the same time, service sector investment has increased sharply despite disinvestment in property.

Fourth, FDIs also involve more firms. Even though the growing influence of large multinational enterprises is one of the defining features of recent trends in international activities, medium-sized enterprises also take a more international approach to their output, employment and financing decisions. ${ }^{10}$ Overall, it is this expansion of the number of countries, sectors and firms involved that has prevented the declining share of manufacturing from causing a trend fall in FDI activities.

Fifth, the forces driving FDI activities and the underlying motives have substantially changed since the pre-WW1 period, with important implications for firms' production and employment decisions. Although gaining access to primary resources was an important motivating force during the early part of this century, FDI outflows mostly reflected attempts to get around artificial and natural barriers to trade. Such outflows favoured a horizontal production structure as similar plants were set up in different countries and affiliate production had only minor effects on parent production, since it complemented rather than replaced exports. In contrast, more recent trends

9 Data for both the United States and Germany indicate that investment in the tertiary sectors abroad can in part be attributed to manufacturing enterprises located in the home country, as the share of manufacturing in outflows is higher than the corresponding shares in inflows in the host countries.

10 Though dominated by multinationals, the pharmaceutical industry also illustrates how small or medium-sized firms get involved through research and developments of certain products, for which they seek foreign partners, or are taken over, when the products reach the marketing stage. 
have been driven by liberalisation and deregulation of both foreign trade and FDIs and, above all, by technological progress which has added new dimensions to the process of integration. ${ }^{11}$ In particular, by enabling firms to "slice up the value-added chain" (Krugman (1995)), the sharp decline in communication costs has created new and more efficient ways of organising production and distribution on a global level. Moreover, in contrast to the earlier period, it has favoured a vertical production structure by allowing firms to arbitrage on factor/price differentials, with potentially stronger interactions between production in both affiliates and parent companies. ${ }^{12}$

Finally, parallel to the steep upward trend of FDI outflows, the number of persons employed by foreign affiliates has increased substantially (Table 6) and, except for the United States, much faster than domestic employment. Moreover, compared with the pre-WW1 period, labour has probably become less mobile and thus less able to absorb, let alone benefit from, the effects of globalisation. For instance, many countries have imposed controls on immigration, especially for workers with lower skills; i.e. those that are most exposed to imports of low-wage products and delocation of production.

Yet it would be premature to conclude that outflows have been associated with exports of jobs or have been a major source of the shifts in the relative demand for skilled and unskilled workers. First, mergers and acquisitions account for $75-80 \%$ of investment outflows. In the short run, such investments only involve a change of ownership and even though, in the somewhat longer run, attempts to cut costs and increase efficiency may lead to downsizing and lay-offs, such measures are not necessarily biased against employees in the parent company. Second, as mentioned above, the industrial countries play a dominant role as both source and host countries while countries which might attract investments through lower labour costs still account for only $30 \%$ of total inward stocks. Moreover, studies of US multinationals suggest that the effects of expanding investment in one lowwage country are mainly felt by workers in other low-wage countries. Third, the firms and sectors that have been most active in investing abroad tend to be technological leaders and not those that have experienced declining employment levels because of competition from low-wage countries (Klodt and Maurer (1996)). Finally, the particularly strong growth of direct investment in the tertiary sectors combined with the fact that, in most cases, services still have to be provided at the location of the

11 Although many restrictions on FDIs have been removed, numerous distortions remain and an international agreement on foreign investment still has many hurdles to overcome. For further discussion, see Ostry (1997) and UNCTAD (1997).

12 Some of the recent technological changes have actually reduced incentives to undertake foreign direct investment. For instance, the marked fall in the transport intensiveness of world trade, as the goods traded are becoming lighter and less bulky, allied with the explosive growth of containers in shipping and deregulation and technical progress in transport on land, have substantially reduced transport costs. This has lowered one natural barrier to trade and an incentive for FDI outflows. Similarly, by reducing the need for physical contact between producer and consumer, modern information technology has also removed a barrier to direct trade in services and, like declining transport costs, an incentive to undertake production abroad. See also Marcusen (1995) who argues that horizontal production structures still dominate. 
consumers, suggests that a substantial part of affiliate production complements rather than replaces exports. In fact, by improving the distribution of goods produced at home, foreign affiliates may help to maintain or expand export market shares.

Table 6

Employment abroad by foreign affiliates

\begin{tabular}{|l|c|c|c|}
\hline & Employment abroad & $\begin{array}{c}\text { Domestic } \\
\text { employment }\end{array}$ & $\begin{array}{c}\text { Employment abroad/ } \\
\text { domestic employment }\end{array}$ \\
\cline { 2 - 4 } & \multicolumn{2}{|c|}{ Percentage changes, annual rates } & Percentages \\
\hline United States & $1.0(1982-96)$ & $1.7(1982-96)$ & $6.0(1996)$ \\
Japan $^{1}$ & $8.6(1984-95)$ & $1.0(1984-95)$ & $3.5(1995)$ \\
Germany $^{2}$ & $3.6(1980-96)$ & $0.3(1980-96)$ & $10.9(1996)$ \\
France & - & - & $10.0(1992)$ \\
Italy $^{3}$ & $9.7(1985-91)$ & $-0.2(1985-91)$ & $15.6(1991)$ \\
Sweden & $5.5(1980-95)$ & $-0.5(1980-95)$ & $6.3(1995)$ \\
Switzerland & $7.2(1986-96)$ & $1.0(1986-96)$ & $38.3(1996)$ \\
\hline
\end{tabular}

${ }^{1}$ Fiscal years. ${ }^{2}$ Western Germany only; employment ratio would be $9 \%$ for total Germany. 3 Manufacturing only.

Sources: US Department of Commerce Survey of Current Business, Deutsche Bundesbank Kapitalverflechtung mit dem Ausland, Swiss National Bank Statistisches Monatsheft, OECD Labour Force Statistics, Parisotto (1995) and national data.

\section{Review of previous work}

While analytical work on the determinants of FDI flows has a long history, most empirical studies have appeared in the 1980s and in particular this decade. Moreover, in step with increasing integration and globalisation more and more variables have been included as possible determinants of FDIs and the focus of interest has been extended to include the channels by which FDI flows influence developments in the home and host countries as well as the size of such effects.

In the following we do not intend to present an extensive or comprehensive overview of the literature. Our more modest aim is to review the studies most relevant to the empirical work in this paper, with particular emphasis on studies that have appeared this decade. It should, however, be recalled that much of the more recent literature builds on the pioneering work of Dunning (1958) and Hymer (1959) and their argument that the motives for undertaking foreign direct investment should be sought in the internal characteristics of MNEs. ${ }^{13}$ Accordingly, three conditions need to be satisfied

13 Previous empirical studies had mostly attempted to explain FDI on the basis of differential rates of return across countries and the gains from portfolio diversification. Similarly, Vernon's (1966) theory that product cycles induce firms to invest abroad received attention in earlier studies. However, like those based on rates of return and diversification, it seems unable to explain developments during the last 20 years and the dominance of flows within the industrial countries. In this context, it is also worth recalling Lizondo's (1991) conclusion that there is no uniquely accepted theory of FDI; instead, various micro- and macroeconomic hypotheses have found some empirical support but not sufficiently to cause others to be rejected except when the motives for FDIs have fundamentally changed. 
before a firm decides to invest abroad: ${ }^{14}$ (i) it must have some ownership-specific advantage which is usually associated with high levels of research and development expenditure, extensive use of and investment in information technologies and a high share of intangible assets in total assets. Moreover, because knowledge-based assets create economies of scale at the firm rather than at the individual plant level and can be moved abroad at almost no cost, they are more likely to induce foreign direct investment than physical assets; (ii) the target country must offer some location-specific advantages, including low relative costs, which makes production abroad more profitable than exports from domestic plants, but also market size and potential growth; and (iii) there must be some internalisation-specific advantages which induce enterprises to use their ownership-specific advantage for their own production rather than licensing it to local firms. As discussed in Marcusen op cit these advantages are closely linked to certain characteristics of knowledge-based capital, such as the fact that it can be used as an input at several plants but also problems due to non-excludability, asymmetric information and incomplete contracting. ${ }^{15}$

The review is in three parts. The first looks at studies which primarily attempt to identify the principal determinants of FDI inflows and outflows and only briefly discuss possible repercussions on home and host countries. The second part reviews work on direct links between employment in the home country and employment in foreign subsidiaries while the third part summarises studies that focus on indirect linkages, notably via home investment, exports and imports.

\subsection{Principal determinants of FDIs}

Market size, trade and openness. An early study of FDI determinants is Culem (1988) who uses panel data for FDI inflows in six industrial countries over the period 1969-82. Among the determinants tested (all referring to host countries and intended to capture aspects of the aforementioned conditions) are market size and growth, previous exports and trade barriers which are all expected to have a positive influence. In contrast, high relative labour costs are assumed to discourage inflows. Except for trade barriers, Culem's priors are largely confirmed, both in the overall sample and in samples analysing flows between the EU and the United States. Culem also concludes that FDI decisions are made independently and are not part of a global investment strategy. However, this result is not supported in more recent studies.

14 These conditions are frequently referred to as the OLI paradigm. However, because the conditions are difficult to quantify, they can best be interpreted as providing a taxonomic framework for selecting other and more representative determinants. Marcusen (1995) surveys the models that have been constructed in the context of ownership-, locationand internalisation-specific advantages and discusses how the activities of multinationals interact with foreign trade.

15 As an illustration, Lizondo mentions software programs which enterprises often prefer to use internally rather than licensing them and running the risk that they are passed on to others. 
The above determinants are also tested by Jost (1997), Martin and Velázquez (1997), Pain and Lansbury (1997) and Wheeler and Mody (1992). In Jost's model for Germany, relative GDP and unit labour costs account for around 70\% of changes in Germany's share of outflows from 14 OECD countries. In explaining the distribution and size of German outflows, Jost tests two alternative models: the first is based on cross-country data and uses per capita income and population size and the second, which is estimated as an error correction model, on time-series data, exports and relative unit labour costs. The results indicate that market size, exports and low levels of labour costs relative to Germany all increase the attraction of a potential host country to German investors. From the error correction model it further appears that adjustments to a change in the key determinants are largely completed within one year.

Pain and Lansbury also look at the determinants of German outflows and confirm Jost's finding regarding market size and relative labour costs. In addition, a high degree of labour market flexibility (measured by the number of strikes) and the stock of patents registered by German firms are found to influence outflows. Similarly, Martin and Velázquez, and Wheeler and Mody also find significant effects of market size and (in the latter case) relative labour costs in their estimates of bilateral FDI flows in Europe and foreign investment by US manufacturers respectively.

Foreign trade has also figured prominently among determinants of FDIs but the expected influence is frequently ambiguous. For instance, since trade barriers provide a motive for FDI inflows, Wheeler and Mody assume (and find this confirmed empirically) that the degree of openness has a negative influence on FDIs. However, in other cases prior knowledge of the host-country market gained through exports may be a precondition for investing, leading to a positive effect of the degree of openness. ${ }^{16}$ As documented by Martin and Velázquez, geographical proximity and common borders also stimulate FDIs through prior knowledge as well as lower transport costs. For instance, in Belgium and the Netherlands, which are both very open economies and centrally located in Europe, inward stocks amount to respectively 38 and 30\% of GDP, compared with 14\% for the European Union as a whole and less than $10 \%$ for the United States. Similarly, Canada accounts for over $16 \%$ of US outward stocks while Canada's GDP is only $2 \frac{1}{2} \%$ of OECD GDP.

One feature of recent international trade developments has been the growth of regional trade arrangements. As is well known, a regional trade agreement has a dual effect on total trade: trade creation within the region due to the removal of trade barriers and trade diversion as trade with third countries is replaced by trade within the region. The effects of regional trade arrangements on FDIs are equally uncertain and largely for the same reasons. On the one hand, the removal of regional trade barriers may reduce FDI flows between member countries as earlier location-specific advantages

16 Recall Jost's model discussed above. See also Marcusen (1997), who constructs a theoretical model for interactions between trade and FDI liberalisation. 
partly disappear. On the other hand, precisely because of potential trade diversion effects, member countries may become more attractive as host countries for investment from third countries. Moreover, a number of factors may act to moderate the effects on intra-regional investment flows. Markets remain differentiated after the removal of trade barriers and positive externalities, and economies of scale effects associated with agglomeration can also stimulate flows within the region. For example, as shown in Pain and Lansbury op cit and European Commission (1998), the Single European Act seems to have imparted a particular stimulus to FDI flows into or from the service sectors and to have induced one-time relocation effects. In fact, when including various proxies for the internal market, both studies find a net positive effect on German and UK direct investment in other EU countries. ${ }^{17}$

Blomström and Kokko (1997) attempt to evaluate integration effects on FDIs for three regional trade agreements: the Canada-US Free Trade Agreement, the NAFTA agreement and the Southern Cone customs union (Mercosur). Their conclusions suggest that a trade agreement between two industrial countries which already have more or less free trade is unlikely to have any major impact on FDI flows. In contrast, when an emerging market country (Mexico) joins an agreement with industrial countries and at the same time undertakes macroeconomic stabilisation, it is likely to experience a major rise in inflows, both from firms within the region, which are attracted by low costs, and from firms outside the region, reflecting trade diversion effects allied with the prospects of being able to serve the whole region from plants located in the new member country. ${ }^{18}$ As regards Mercosur, initial data indicate that it may have encouraged tariff-jumping inflows and that countries such as Argentina and Brazil, with ample supplies of natural resources and large markets, have benefited most from such inflows.

Mergers, acquisition and corporate finance. Considering the weight of mergers and acquisition in FDIs, corporate finance structures in the host countries are likely to play a major role in determining the size and, in particular, the distribution of FDIs across countries. As noted by Jost (1997), likely candidates for inflows are countries such as the United States and the United Kingdom, in which equities are a major external source of financing investment and many companies are listed on the stock exchange. In contrast, mergers and acquisitions are difficult in Germany and Japan, where

17 The 1998 study commissioned by the European Commission contains a detailed discussion of how the single market programme has affected trade and FDIs as well as econometric studies. The latter are confined to German and UK outflows and based on panel data, using the number of patents, GDP, financial variables (debt/income ratio and user cost of capital) and relative unit labour costs as the principal determinants in addition to proxies for the single market. For Germany, a dummy variable for exchange rate volatility is also significant while tax rates are of only marginal importance (and frequently of the "wrong" sign) for both countries. A further result is that increased outflows to other EU countries has, in part, been at the expense of outflows to other countries, though the displacement effect is relatively small.

18 One feature of the 1980s has been the increasingly regional nature of FDIs as firms frequently chose host countries that were suitable as a base for serving a whole region (see Oman (1994) and Wells (1994)). According to Kozul-Wright and Rowthorn (1998), this trend has continued into the 1990s. 
bank credit is the principal source of external finance, relatively few firms are listed and crossholdings are widespread. ${ }^{19}$ Similarly, borrowing costs in both home and host countries can influence the size of measured FDI flows. For instance, higher borrowing costs in the source country may induce parent companies to finance investment by foreign affiliates through local borrowing rather than by equity or debt transfers. ${ }^{20}$ At the same time, differences in borrowing costs between potential host countries affect parent companies' decisions with respect to the location of investment.

The impact of rates of return and equity prices has also been tested in this context. Differential rates of return were key determinants in some of the earlier studies mentioned above, but lost their explanatory power in the 1970s and 1980s. Moreover, as seen in the estimates by Pain and Lansbury op cit, if outflows are mainly to be explained by the behaviour of MNEs, a high rate of return on their domestic investment or a strengthening of their capital base through higher equity prices may, in fact, stimulate outflows.

Exchange rates and costs of production. Another set of variables that influence the size and distribution of FDI flows are factors related to costs. ${ }^{21}$ As noted above, the appreciation of the yen had a major impact on total FDI flows in the second half of the 1980s and this result is further supported in Bayoumi et al. (1996) and Goldberg and Klein (1998). In both studies, real bilateral exchange rates against the yen have had a significant influence on investment inflows into other APEC countries and a subgroup of South-East Asian countries respectively, whereas real bilateral rates against the US\$ have had only a marginal impact. Significant exchange rate effects are also reported in Culem op cit, Jost op cit, Caves (1989), Cushman (1985), Froot and Stein (1991) and Bayoumi and Lipworth (1997) (see below). Similarly, the results for the United Kingdom and Germany in Hatzius (1997a) show that a "high" real exchange rate (measured by relative unit labour costs) in home (host) countries tends to encourage outflows (discourage inflows). ${ }^{22}$ When combined with additional evidence (Hatzius (1997b), see below), it further appears that the influence of relative labour costs has increased with the removal of barriers to FDI flows.

19 Various regulations, notably for banks and insurance companies, also make Germany and Japan unattractive to foreign investors; see Klodt and Maurer (1996).

20 See earlier note on US FDI outflows in the early 1980s.

21 Relative costs of production are, however, not the principal, let alone the only, determinant in firms' decisions about location. In fact, several studies model location decisions as a two-stage process where the total amount of global or regional investments is determined at the first stage and the distribution by country at the second stage. Typically, costs of production only enter at the second stage (see, for instance, Barrell and Pain (1997)).

22 While there is a general consensus regarding the effects of exchange rate levels or changes, views on the effect of exchange rate volatility are mixed. Some argue that greater volatility stimulates FDIs as foreign investment provides insurance against future currency changes. Others see greater volatility as discouraging FDIs due to the irreversibility of investment against the risk that exchange rates reverse. For further discussion and evidence of mainly positive effects, see Goldberg and Kolstad (1995), Stockman and Vlarr (1996), Hubert et al. (1997) and Pain and Lansbury op cit. 
Exchange rate developments also figure prominently in Klein and Rosengren's (1994) study of US inflows and in their attempt to distinguish between two effects: (i) a cost effect, as a country with a "low" or depreciating exchange rate becomes more attractive to foreign investors, assuming that the exchange rate depreciation is not seen as temporary; and (ii) a wealth effect, whereby an appreciation increases the financial wealth of potential parent companies and thus strengthens their "bidding" power with respect to mergers and acquisitions. ${ }^{23}$ Their empirical results strongly favour the wealth effect, as an equation incorporating separate terms for relative wages and relative stocks of wealth yields an insignificant coefficient for the former.

Exchange rates and the volatility of exchange rates are, of course, not the only variables affecting costs of production. As discussed elsewhere, labour and capital costs are also important. In addition, differential tax rates and various fiscal incentives and subsidies can influence firms' location decisions. Since comparable data for tax rates applying to MNEs are difficult to construct (see Jost op cit and Leibfritz et al. (1997)), significant tax effects have been identified in only a few studies. However, using data on tax returns by US multinationals, Altschuler et al. (1998) are not only able to estimate high and significant tax elasticities but, in addition, find a significant increase in such elasticities as FDI flows have been liberalised. ${ }^{24}$ There is also evidence that fiscal incentives help explain the concentration of foreign-owned holding companies in Belgium and the Netherlands. Moreover (Ruane and Görg (1997)), FDI inflows into "high-tech" manufacturing sectors in Ireland can be attributed to tax exemptions for foreign companies, combined with cash grants and a commitment by policy-makers to continue such policies.

\subsection{Direct linkages between foreign and domestic employment}

Labour substitution and employment. Several papers have evaluated employment linkages by estimating translog cost functions, in which the coefficients of relative wages can be regarded as substitution elasticities. For instance, in two companion papers based on panel data for US multinationals and their affiliates in 90 countries, Brainard and Riker (1997a and 1997b) estimate substitution elasticities between employees in parent companies and their foreign affiliates as well as between employees in affiliates disaggregated by geographical location and stage of development of the host country. Among their main findings is a very low degree of substitution between parent and

23 While the specifications in Culem op cit and Jost op cit are based on cost effects, Froot and Stein (1991) provide the analytical framework for estimating wealth effects. In support of the latter, see also Harris and Ravenscraft (1991), who find that buyers from strong-currency countries pay high premia relative to domestic buyers for the acquisition of US assets, as well as Dewenter (1995), who explores variations in premia across industries and investor countries.

24 According to Altschuler et al. (1998), the elasticity of real capital expenditure by US foreign affiliates with respect to effective tax rates in the host country was as high as 2.7 in 1992, up from 1.5 in 1984 . Note that the elasticity refers to the choice between different foreign locations and not to the choice between investing at home or abroad. 
affiliate employment. In contrast, employees in affiliates in different emerging market countries are found to have a very high degree of substitution, whereas the relationship between employees in affiliates in industrial countries and emerging market countries is one of complementarity. All in all, the results point to a vertical production structure in which MNEs attempt to minimise costs by distributing production globally according to differences in skills and wages.

Slaughter (1995) uses a very similar methodology, except that he confines his analysis to production workers; i.e. those employees that are most exposed to potential displacement effects. He also finds a very low degree of substitution between employees in parent companies and their foreign affiliates; in fact, when the capital stock is allowed to vary, the relationship is one of complementarity. As further proof against the claim that MNEs have been exporting jobs, he notes that affiliate employment of production workers does not seem to be systematically related to relative parent/affiliate wages and has actually fallen over the period 1977-89.

Hatzius (1997b) and Döhrn (1997) can also be interpreted under the heading of labour substitution and employment. Hatzius poses the question whether Swedish MNEs vary their distribution of labour demand in response to wages in Sweden and a range of host countries respectively. The results indicate that labour demand is highly responsive to wages in actual and potential host countries but not to wages in Sweden. This asymmetry is somewhat odd but might suggest that, as in the United States, substitution elasticities are rather low. ${ }^{25}$ Döhrn's analysis is based on panel data for more than 100 German multinational firms and attempts to explain the share of employment by foreign affiliates in total employment. His estimates suggest that firms with labourintensive production tend to have a high share of foreign employment whereas capital-intensive firms have a lower share. ${ }^{26}$ Döhrn further finds that firms with a high rate of return are more likely to invest abroad than firms with low returns (see also Klodt and Maurer op cit) while the impact of firm size (measured by turnover) follows a U-shaped pattern.

Because of the low degree of substitution between employees in parent companies and their foreign affiliates, the above results suggest that, even though there may have been some displacement of home-country workers via foreign investment, such effects are likely to have been only moderate. Yet, for several reasons, the substitution elasticities may understate the effects. First, the elasticity estimates may be biased by including only manufacturing MNEs. As noted above, US manufacturing reached a turning point in the late 1970s which significantly affected employment trends at home and abroad during the 1980s. Second, even though Brainard and Riker op cit find that

25 Although Hatzius does include control variables, most of them are insignificant and the explanatory power of the estimated equations is rather low $\left(\mathrm{R}^{2} \mathrm{~s}\right.$ mostly around 0.3$)$.

26 As the author notes, the direction of causality between foreign/domestic employment shares and the factor intensity of production is ambiguous. 
affiliate employment in industrial countries and emerging market countries are complements, they note that affiliate employment has shifted to those emerging market countries where wages have been falling relative to wages in developed countries. Third, notwithstanding Slaughter's finding of complementarity when the capital stock is variable, the notion of a vertical production structure across borders seems to involve some displacement of production or low-wage workers, compared with the situation where all production takes place at the parent company. In other words, while parent and affiliate workers may be complements once affiliate plants have been set up, displacements are likely to have occurred during the process of redistributing total production and employment according to relative costs and wages.

Our own estimates are also suggestive of displacement effects. ${ }^{27}$ As Table 7 shows, employment in US affiliates is significantly influenced by relative wage levels in industrial as well as emerging market host countries. Moreover, even if affiliate production does not directly affect home production, the fact that the labour intensity of output varies significantly with wage costs is likely to influence home employment. ${ }^{28}$

Table 7

\section{Determinants of employment in US affiliates*}

\begin{tabular}{|l|c|c|c|c|c|c|}
\hline Equation & Intercept & Output & Labour costs & $\mathbf{R}^{\mathbf{2}}$ & Standard error & Sample size \\
\hline (a) & $-3.76(5.4)$ & $1.10(20.7)$ & $-0.42(2.7)$ & 0.96 & 0.28 & 20 \\
(b) & $-4.31(7.6)$ & $1.06(16.1)$ & $-0.29(5.0)$ & 0.90 & 0.38 & 30 \\
\hline
\end{tabular}

* Coefficients obtained by estimating the following equation across US affiliates, with (a) confined to industrial countries and (b) also including ten emerging market countries with affiliate output exceeding US\$2 billion (1994 data):

$\log e m_{i}=\alpha+\beta \log y_{i}+\delta \log w_{i}+\varepsilon$

where $e m_{i}$ denotes employment by US affiliates in country $i, y_{i}$ affiliate output in country $i, w_{i}$ hourly labour costs (manufacturing) in country $i$ and $\varepsilon$ a random error. Initially, the estimates also included assets held by the affiliates but the coefficient was always negative and insignificant.

Sources: US Department of Commerce Survey of Current Business and Morgan Stanley International Investment Research.

Affiliate production and home-country employment. Evidence of displacement effects is also found in a series of panel studies by Lipsey. The empirical approach (see Lipsey and Kravis (1988), Lipsey (1994) and Blomström et al. (1997)) is based on the following equation:

$E m_{p}=\alpha+\beta x_{p}+\delta x_{a, i}+\phi x_{a, d}+\varepsilon$

where $E m_{p}$ is employment in parent company, $x_{p}$ output in parent company, $x_{a, i}$ output in affiliates located in industrialised countries, $x_{a, d}$ output in affiliates located in emerging market countries, and

27 See also Zhao (1998) who analyses employment and wage effects of FDIs, using a Nash bargaining model.

28 Lipsey also notes that differences in labour intensities of production may induce changes in parent employment as well as in the skill composition of labour demand, even if there is no effect on parent production. 
$\varepsilon$ a random error. For US multinationals, parent production obtains a positive coefficient whereas the coefficients on affiliate production is negative. In other words, even controlling for parent production, affiliate activities reduce the demand for labour in the home country. Moreover, the very large negative coefficient for affiliates in emerging market countries suggests that demand for low-skilled employees may be particularly adversely affected.

However, when the same equation is estimated for Sweden, there is no evidence that affiliate activities adversely affect parent employment as the output coefficients are positive. It also appears that affiliate activities mainly increase the demand for production workers in Sweden, suggesting that management, research and other overhead activities are located abroad. For affiliates in emerging market countries, however, the impact on parent employment is positive for all workers.

\subsection{Indirect linkages between foreign and domestic employment}

Investment. Most of the empirical studies of indirect relations are of a partial equilibrium nature as they focus on production and investment decisions for a sample of MNEs. Feldstein (1994) is an exception to this as he attempts to answer the question as to how much one unit of FDI outflows will reduce total domestic investment. The empirical approach is essentially an extension of the Feldstein-Horioka (1980) equation to include FDI flows, as well as other variables that might jointly influence FDIs and domestic saving and investment. ${ }^{29}$ His preferred equation implies a 1:1 trade-off between FDI outflows and domestic investment whereas the coefficient on inflows is insignificant. The saving retention coefficient is estimated at 0.75 and is largely independent of whether or not FDIs are included. It thus appears that a one unit rise in outflows does not induce any offsetting financial inflows but leads to a corresponding decline in domestic investment. ${ }^{30}$

However, this is not the "whole story", as changes in assets controlled abroad exceed FDI outflows. Indeed, as Table 8 shows, such assets change by a multiple of outflows as additional assets are financed either in the host country or from third-country sources. These additional sources of finance have two implications. First, because the foreign assets controlled by MNEs significantly exceed outflows and outward stocks, the scope for export substitution or complementarities is vastly expanded although the net effect remains ambiguous. Second, because a major part of the additional

29 More specifically, the following equation is estimated on average data across 15-18 OECD countries:

$I / Y=\alpha+\beta S / Y+\chi F D I_{\text {out }}+\delta F D I_{\text {in }}+\phi Z+\varepsilon$

where $I$ is gross fixed domestic investment, $S$ gross domestic saving, $Y$ GDP, $F D I_{\text {out }}\left(F D I_{\text {in }}\right)$ foreign direct investment outflows (inflows), $Z$ other variables, and $\varepsilon$ a random error. According to Devereux (1996), the interaction between foreign and domestic investment is highly dependent on the nature of FDI. Thus certain activities may actually require additional domestic investment while others lead to a 1:1 negative relationship and some have no effect.

30 In terms of the original Feldstein-Horioka hypothesis, the result also suggests that the fragmentation of international capital markets implied by the saving retention ratio does not apply to, or is circumvented by, FDI flows. 
sources consists of debt finance, the overall debt/equity ratios of MNEs and thus their marginal borrowing costs will be affected by investment abroad. In other words, increases in FDIs may also affect parent employment by raising financing costs for domestic investment.

Table 8

Foreign direct investment outflows and changes in foreign assets In billions of US dollars

\begin{tabular}{|l|c|c|c|}
\hline & United States, 1994 & Japan, 1992 & Germany, 1995 \\
\hline Equity outflows & 12.7 & 17.2 & 28.9 \\
Retained earning & 31.7 & -1 & 1.4 \\
Intra-firm debt & 6.6 & -0.2 & - \\
Other domestic sources & -22.8 & 4.1 & $4.6^{2}$ \\
Host-country sources & 59.4 & 3.0 & - \\
Sources other countries & 117.6 & 43.2 & $35.1^{3}$ \\
Change in foreign assets & 205.2 & 67.3 & 70.0 \\
\hline
\end{tabular}

1 Data for Japanese manufacturing enterprises suggest that in some years retained earnings have added up to $40 \%$ to recorded outflows. 2 Sum of changes in intra-firm debt and other domestic sources. ${ }^{3}$ Sum of host-country sources and sources other countries.

Sources: UN World Investment Report and IMF Balance of Payments Statistics.

This second link is the subject of Stevens and Lipsey (1992) who examine whether decisions by MNEs to invest abroad influence their investment at home via financial interactions. In a first set of tests they use debt/equity ratios as a proxy for financial linkages and mostly find significant and negative coefficients. ${ }^{31}$ The second set of (reduced-form) tests, where own funds and output in parent companies and affiliate companies are used as proxies, is less conclusive. While the coefficients on own funds and own output are positive and significant, those on affiliate output vary across firms and equations, probably indicating that investment in or by foreign affiliates is associated with substitution as well as complementarity effects. As noted by the authors, these tests also help to explain why bilateral correlations between investment by parent companies and their foreign affiliates tend to be significantly positive as they are dominated by common shocks acting through the own funds variable and, in cases of complementarity, also through the output variables.

At the same time, estimates for Japan (Bayoumi and Lipworth (1997)) show no displacement effects for domestic investment, though, in part, this may be due to the specification of the model. On the assumption that investment activities in Japan as well as in host countries can be used to identify the motives for undertaking FDIs, the following equation is estimated on panel data for Japan and 20 host countries:

$\Delta \log F D I_{i}=\alpha+\beta \Delta \log I_{j a}+\delta \Delta \log I_{i}+\phi \log e_{j a, i}+\varphi \Delta \log$ Stock $_{i,-1}+\varepsilon$

31 More specifically, Stevens and Lipsey estimate separate domestic and foreign investment equations for each of seven US multinationals and, for 11 of the 14 equations, the debt/equity ratio obtains a negative and significant coefficient. 
where $F D I_{i}$ denotes Japanese direct investment in country $i, I_{j a}$ fixed investment in Japan, with $\beta$ assumed to indicate the strength of FDIs motivated by vertical integration of production, $I_{i}$ fixed investment in country $i$, assuming that investment correlates with general economic activity in country $i$ and $\delta$ expected to capture FDIs motivated by a desire to serve local markets more efficiently, $e_{j a, i}$ the bilateral real yen exchange rate, with $\phi$ assumed to be negative for both motives, Stock $k_{i,-1}$ the lagged stock of foreign investment in country $i$, and $\varepsilon$ a random error term.

Table 9

Regional and sectoral composition of Japanese outflows

Cumulative total flows, in percentages

\begin{tabular}{|l|c|c|c|c|}
\hline \multirow{2}{*}{} & \multicolumn{2}{|c|}{ By region } & \multicolumn{2}{c|}{ By sector } \\
\cline { 2 - 5 } & OECD countries & Asia & Secondary & Tertiary \\
\hline $1982-89$ & 70.5 & 13.1 & 24.5 & 70.7 \\
$1990-95$ & 70.8 & 18.3 & 31.1 & 64.8 \\
1995 & 67.0 & 24.0 & 36.8 & 58.8 \\
\hline
\end{tabular}

Source: OECD International Direct Investment Statistics.

Their results show that $I_{j a}$ has a positive and significant influence, suggesting that Japanese outflows have mostly been driven by the integration motive and thus acted as a complement to domestic investment. The real bilateral exchange rate has the expected negative coefficient while the coefficient on $I_{i}$ is positive but much smaller than $\beta$. Nonetheless, even though the equation seems robust to alternative specification, the efficiency motive may be understated. First, as noted by the authors, the sample period is dominated by the boom and bust in the Japanese asset price cycle. Second, investment in host countries may not be the best indicator of general activity and, in particular, does not account for sales by affiliates to third countries. Third, the finding that the coefficient on $I_{i}$ does not vary across host countries is at odds with changes in the compositions of Japanese outflows. As Table 9 shows, both the sectoral and regional distributions changed significantly between the 1980s and the 1990s and this shift is likely to have been accompanied by a shift in the dominating motive and in the linkages to investment in Japan.

Foreign trade. Since Mundell's (1957) ground-breaking work on the substitutability between factor mobility and foreign trade, the question of whether FDI outflows affect domestic output and employment through changes in foreign trade has been a hotly debated issue. ${ }^{32}$ While there is a general consensus that outflows reduce domestic employment through higher imports

32 Kojima (1985) defines FDIs as trade-oriented if they generate excess demand for imports and excess supply of exports and, if the opposite occurs, as anti-trade-oriented. The argument behind this distinction, which has found only limited empirical support, is that in the former (latter) case FDIs will be in industries in which the source country has a comparative disadvantage (advantage). 
(i.e. imports and outflows are complements and mostly via intra-firm imports of intermediate goods) the key issue is whether exports and outflows are substitutes or complements. Most studies for the United States (Lipsey and Weiss (1981 and 1984), Blomström et al. (1988), Hufbauer et al. (1994) and Lipsey (1994)) conclude that there is a weak complementary relationship between outflows and exports and similar results have been found for Austria and Germany (Hufbauer et al. op cit, Klodt and Maurer op cit and Pfaffermayer (1994)), France (Fontagnë and Pajot (1997)) ${ }^{33}$ and Sweden (Swedenborg (1985) and Blomström et al. (1988)). However, there are exceptions to these results. For instance, Svensson (1996) claims that because of affiliate exports to third countries the overall effect on parent exports is negative even though exports to the host country of the affiliate increase. ${ }^{34}$ Moreover, after controlling for price and non-price competitiveness, Pain and Wakelin (1996) find long-run substitution effects for most European countries and the United States, but not for Japan.

In the case of Germany, Jost's (1997) error correction model reveals significant short and long-run positive relationships between exports and outflows. With about two-thirds of the regional distribution of German outflows explained by the distribution of exports, the estimated relationships are suggestive of complementarities in production as well as of the importance of prior knowledge of potential host countries. Yet, while prior knowledge implies that outflows follow exports, the crucial issue is whether this positive relationship remains once the foreign capital expansion has been completed. On this point, the estimates by Bayoumi and Lipworth (1997) and Goldberg and Klein (1998) are instructive as the former find that the positive relationship reported by Pain and Wakelin is confined to the "building-up" phase when Japanese firms benefit from increased exports of investment goods. 35 Once the foreign plants are completed, the main effect is in the form of higher imports into Japan. In contrast, Goldberg and Klein find strong complementarity between Japan's investment in South-East Asia and exports from and imports into Japan, a result that is also supported by parallel estimates for Japanese investment in Latin America.

With respect to inflows and foreign trade, several studies, notably for South-East Asian countries, have identified a complementary relationship between inflows and exports. In some cases, this reflects performance-based restrictions but there is also evidence of positive spillover effects on

33 The complementarity between exports and outflows can to a large extent be attributed to large spillover effects in the source country (France). The authors further find that outflows generate additional imports and that inflows are also complements to exports as well as imports, with the net result that a balanced rise in inflows and outflows is associated with a small deterioration of the trade balance for France. When using stocks instead of flows, the evidence is less supportive of complementarities, though the above result with respect to the net trade balance also holds for a balanced rise in inward and outward stocks.

34 According to Lipsey (1994), Svensson's result depends on his normalisation of the dependent and independent variables which essentially implies that world output of the parent company is constant.

35 More specifically, Bayoumi and Lipworth find that FDI outflows are positively correlated with exports whereas the stocks of FDI have no influence. They also find that the absence of any long-run relationship can be attributed to offsetting trends for exports of capital goods and consumer goods. 
exports from local firms. Inflows and imports are complementary when affiliates buy intermediate goods from parent companies. However, in several countries, local content requirements have weakened this relationship and, in the case of "tariff jumping", inflows and imports are substitutes.

\section{Empirical estimates of FDI inflows and outflows}

\subsection{Panel regressions}

This subsection attempts to identify determinants of outflows and inflows, using panel data for 21 countries. In the following subsection, these results are then complemented and compared with estimates based on time-series regressions for four of the major countries. As noted above, most recent studies stress specific advantages related to ownership, location and internalisation as the primary motives behind firms' decisions with respect to the global distribution of their output. These advantages also served as a framework for our choice of potential determinants. More specifically, the dependent variable in all the equations to be reported below refers to bilateral flows, cumulated over the period 1985-95 or bilateral stocks, by end-1995. ${ }^{36}$ Moreover, in identifying the determinants of inflows and outflows (respectively inward and outward stocks), we applied a procedure which, in some sense, "reverses" the bilateral flows. Thus, when attempting to explain the determinants of outflows, we used the following equation:

$$
F D I(i)_{i, j}=\alpha+\beta \Delta Y_{j}+\chi I / Y_{j}+\delta \Delta I t_{j}+\phi E x / Y_{j, i}+\gamma I r_{j}+\eta \Delta e_{j}+\lambda \log L c_{j}+\kappa E U_{i, j}+\varepsilon
$$

where:

$F D I(i)_{i, j}=$ cumulative inflows in country $i$ from country $j$, with $j$ referring to all the investors in $i$,

$\Delta Y_{j}=$ average growth of GDP in country $j$ (1984-95), on the assumption that fast-growing countries have more funds to invest abroad or might have reached a point where the return on capital invested at home is relatively low, ${ }^{37}$

$I / Y_{j}=$ fixed investment relative to GDP of country $j$ (1990), to test whether countries with high domestic investment are more likely to invest abroad than countries with low capital formation, ${ }^{38}$

36 Both flows and stocks are measured in US dollars and entered as logarithms. We also entered the left-hand variables, measured as shares of total flows or stocks, but results were less satisfactory than those reported below.

37 We also used the level of GDP in country $j$ on the assumption that "rich" countries have more funds to invest. The results did not reject the hypothesis but were, again, less satisfactory than those reported below. On the other hand, splitting the level of GDP into per capita income and population size did not work.

38 Since investment abroad may influence the level of domestic investment (see Section 4), the 1990 investment ratio rather than the end-period level was used. For similar reasons, the export and import ratios (see below) were entered with their 1990 levels. We also considered indices of global competitiveness as reported by the World Economic Forum. However, the signs of the estimated coefficients implied that the least competitive countries were the most likely candidates for inflows and the most active foreign investors. 
$\Delta I t_{j}=$ average growth of sectors producing information technology in country $j$ (1987-94), on the assumption that ownership-specific advantages and incentives to invest abroad are positively related to prior investment in research and development and/or to firms and sectors that are extensive users of information technology,

$E x / Y_{j, i}=$ exports of goods from country $j$ to country $i$, relative to GDP of country $j$ (1990), to test the hypothesis that bilateral trade flows and prior knowledge stimulate outflows,

$I r_{j}=$ long-term interest rate of country $j$ (1990), assuming that financial costs in the source countries might affect outflows,

$\Delta e_{j}=$ average change in bilateral exchange rate of country $j$ against country $i$ (1984-95), assuming that countries with appreciating exchange rates (indicated by a positive figure for $\Delta e_{j}$ ) are more active foreign investors than countries with depreciating exchange rates, ${ }^{39}$

$L c_{j}=$ hourly labour costs (in US dollars) in manufacturing in country $j$ (1995), to see whether high labour costs tend to stimulate outflows, 40

$E U_{i, j}=$ dummy variable for EU member countries, assuming that regional trade arrangements might influence the size and distribution of bilateral FDI flows. ${ }^{41}$

Similarly, to identify the determinants of inflows we used the following equation:

$$
F D I(o)_{i, j}=\alpha^{\prime}+\beta^{\prime} \Delta Y_{j}+\chi^{\prime} I / Y_{j}+\delta^{\prime} \Delta I t_{j}+\phi^{\prime} \operatorname{Im} / Y_{j, i}+\varphi^{\prime} \log (L * T u / C)_{j}+\gamma^{\prime} I r_{j}+\eta^{\prime} \Delta e_{j}+\lambda^{\prime} \log L c_{j}+\kappa^{\prime} E U_{i, j}+\mu
$$

where:

$F D I(0)_{i, j}=$ cumulative outflows from country $i$ to country $j$, with $j$ referring to all the countries in which country $i$ is investing,

$\Delta Y_{j}=$ average growth of GDP in country $j$, assuming that market growth potential is relevant when firms consider a potential foreign location,

$I / Y_{j}=$ fixed investment relative to GDP of country $j$, to test whether a high investment ratio discourages or encourages inflows,

$\Delta I t_{j}=$ average growth of sectors producing information technology in country $j$. While we expected a positive coefficient in equation (3.1), the a priori sign is ambiguous in (3.2). On the one hand, it may

39 It might have been preferable to use PPP exchange rates or deviations from such rates for both outflows and inflows. However, since PPPs are both difficult to measure and sector-dependent, we used bilateral rates, measured as changes from an arbitrarily chosen base year.

40 As noted by Jost (1997), more satisfactory results might be obtained when relative unit labour costs or a price deflator for the total economy are used instead of relative labour costs for manufacturing. Unfortunately, comparable labour cost figures are difficult to construct for the aggregate economy.

41 Countries that have been members since 1986 were given a weight of 1 , countries that joined in the 1990s a weight of $1 / 2$ and non-member countries a weight of 0 . In the estimation, $E U_{i, j}$ was entered as a sum, corresponding to the member status of the source and host countries. We experimented with intercept as well as slope dummies but the latter mostly gave implausible signs except when the estimates were confined to cross-country estimates for some non-EU countries. 
be argued that knowledge of new technologies encourages inflows as prospective investors are certain of finding workers and suppliers with the necessary skills and technical equipment. On the other hand, as argued by Agarwala (1997), technical superiority could discourage inflows as prospective investors would need to possess at least the same degree of technical skill,

$\operatorname{Im} / Y_{j, i}=$ imports of goods of country $j$ from country $i$, relative to GDP of country $j$, to test whether prior trade flows or openness encourage inflows,

$\left(L^{*} T u / C\right)_{j}=$ number of listed companies times turnover relative to capitalisation in country $j(1995)$, to test whether the size of and activity in equity markets encourage inflows by facilitating mergers and acquisitions, ${ }^{42}$

$I r_{j}=$ long-term interest rate of country $j$, on the assumption that the level of interest rate in the host country may influence capital expansion plans of foreign firms and the share to be financed locally, $\Delta e_{j}=$ average change in bilateral exchange rate of country $j$ against country $i$ (a positive figure indicates an appreciation of the currency of country $j$ ) on the assumption that countries with depreciating exchange rates, and thus lower costs and equity prices, might be more attractive to foreign investors than countries with appreciating exchange rates,

$L c_{j}=$ hourly labour costs (in US dollars) in manufacturing in country $j$, to test the hypothesis that low labour costs appeal to foreign investors,

$E U_{i, j}=$ dummy variable for EU member countries, as described above.

In estimating the above equations, we allowed the intercept term to vary by country and initially included all the potential determinants listed above. After successive elimination of those with low t-ratios, the results (Table 10) may be summarised as follows:

(i) Output growth is an important determinant of outflows but, contrary to the results of most other studies, not of inflows. It thus appears that countries with relatively high output growth tend to be among the most active investors abroad whereas potential market growth is not a principal factor when firms consider a foreign location among industrial countries. ${ }^{43}$

(ii) Bilateral trade flows have a significant influence on both outflows and inflows, with the sign of the coefficients suggesting that prior knowledge through trade stimulates FDI flows.

(iii) High growth in IT producing sectors tends to attract inflows and boosts outflows as well, underlining the extent to which FDI activities are associated with knowledge-based capital and

42 Initially, each of the three variables was tested as a separate proxy for corporate finance structures but in most cases, a combination of the three into one indicator provided the most satisfactory results; in some regressions capitalisation alone was the dominating factor.

43 When $\Delta y$ was included, the coefficient was positive but insignificant. It is possible that the range of growth rates of the countries in the sample is not sufficiently wide to influence firms' choice of location. The insignificance of $\Delta y$ may also be related to the inclusion of $I r$ in equation (3.2) as $I r$ is positively correlated with $\Delta y$ as well as the level of GDP. 
innovations in this area have acted as a major stimulus to globalisation.

(iv) Stock market capitalisation and trading are also important determinants of FDIs. While we had expected this variable to influence firms' choice of foreign location, the equally important role of this variable as a determinant of outflow was unexpected. However, one explanation for this result might be that the equity market variable is merely acting as a proxy for the growing proportion of FDIs accounted for by mergers and acquisitions.

(v) The investment/GDP ratio appears with a positive coefficient in both inflow and outflow equations. This suggests that countries with a high ratio of investment to GDP are more likely to invest abroad than countries with low rates of capital formation and that a high investment ratio has a positive effect on inflows.

(vi) Exchange rate changes are significant in all four equations, with the signs implying that countries with appreciating currencies are less likely to attract inflows and more likely to invest abroad. It also appears that countries with relatively high labour costs are less likely to attract inflows and more likely to seek a foreign location for their production than countries with relatively low costs.

(vii) Interest rates only seem to influence inflows and the negative sign implies that countries with high interest rates are less attractive to foreign investors than countries with low rates.

(viii) Finally, EU member countries, cet. par., seem to receive a higher share of outflows than non-member countries and are also more active as source countries. Moreover, the definition of the dummy variable, combined with the relative size of the intercept shifts (Annex Tables $3 a$ and $3 b$ ) for panels of respectively member and non-member countries, implies that the trade agreement has increased rather than reduced FDIs among member countries.

Table 10

Determinants of foreign direct investment flows and stocks

Pooled estimates

\begin{tabular}{|l|c|c||c|c|}
\hline \multirow{2}{*}{ Determinants } & \multicolumn{2}{|c||}{ Outflows/stocks (equation 3.1) } & \multicolumn{2}{c|}{ Inflows/stocks (equation 3.2) } \\
\cline { 2 - 5 } & Cumulated outflows & Outward stocks & Cumulated inflows & Inward stocks \\
\hline$\Delta Y$ & $0.35(6.0)$ & $0.36(6.2)$ & - & - \\
$I / Y$ & $0.12(3.3)$ & $0.12(3.0)$ & $0.12(2.4)$ & $0.10(2.1)$ \\
$\Delta I t$ & $1.38(5.7)$ & $1.68(6.7)$ & $0.76(3.3)$ & $0.61(2.7)$ \\
$E x / Y \quad(I m / Y)$ & $0.20(4.1)$ & $0.22(3.9)$ & $0.22(4.2)$ & $0.22(4.0)$ \\
$\log \left(L^{*} T u / C\right)$ & $0.84(10.6)$ & $0.80(9.5)$ & $0.20(2.3)$ & $0.27(3.0)$ \\
$I r$ & - & - & $-0.62(6.3)$ & $-0.57(5.9)$ \\
$\Delta e$ & $0.13(2.6)$ & $0.17(3.6)$ & $-0.48(4.4)$ & $-0.37(3.5)$ \\
$\log L c$ & $0.97(2.4)$ & $0.53(1.3)$ & $-0.94(2.6)$ & $-1.10(3.1)$ \\
$E U$ & $1.45(5.0)$ & $1.09(3.6)$ & $3.27(6.7)$ & $2.78(5.8)$ \\
$\mathrm{R}^{2}$ & 0.66 & 0.72 & 0.64 & 0.67 \\
Standard error & 1.5 & 1.3 & 1.4 & 1.3 \\
\hline Countries & 21 & 13 & 19 & 14 \\
Observations & 333 & 223 & 304 & 255 \\
\hline
\end{tabular}


All in all, the estimates in Table 10 suggest that FDIs are driven primarily by trade, equity market developments, IT intensive production, and prior investment/output ratios. However, relative costs are also important as countries with depreciating exchange rates and low labour costs attract inflows, while countries with appreciating exchange rates and relatively high labour costs are likely to be found among foreign investors. However, it is uncertain, whether the effects of exchange rate movements on FDIs are transmitted via changes in relative costs or changes in relative wealth, though the very high stock market influences in all four equations point to the latter.

\subsection{Time-series regressions}

As a supplement to the above results, Table 11 shows time-series estimates for four countries, for which sufficiently long data series are available. Since the panel regressions were based on cumulative bilateral flows while, in this section, we look total flows and their developments over time, the regression results are only partly comparable. Thus trade patterns are disregarded in this section and exchange rate movements are measured by changes in nominal or real effective rates rather than by bilateral rates. Income levels and average rates of growth are also disregarded while the relationship between FDIs and domestic investment is analysed in the next section. In contrast, given the procyclical behaviour of FDIs, the output gap is included among the determinants while the influence of equity markets and relative wealth are proxied by changes in average equity prices and nominal exchange rates. The estimating procedure in this subsection also differs from that applied above. Because outflows and inflows, as well as most of their determinants, are non-stationary variables (see Annex Table 4), we chose an error correction model and implemented it using the Engle-Granger two-step procedure: 44

$$
\Delta z_{t}=\alpha+\lambda e c m_{t-1}+\beta_{1} \operatorname{Gap}_{t}+\beta_{2} \operatorname{Gap}_{t-1}+\delta \Delta I r_{t-1}+\phi \Delta \log e_{t-1}+\varphi \Delta \log r e_{t-1}+\eta \Delta \log (e * e q)_{t-1}+\varepsilon_{t}
$$

where $z$ denotes FDI inflows or outflows (measured in logs), Gap the output gap, Ir a corporate or industrial bond rate, $e$ the nominal effective exchange rate, $r e$ the real effective exchange rate, $e q$ equity prices and $e c m_{t-1}$ the lagged residual from the correponding cointegration equations, written as:

$$
z=\alpha^{\prime}+\beta^{\prime} G a p+\delta^{\prime} I r+\eta^{\prime} \log (e * e q)+\kappa R e t u r n+\varepsilon^{\prime}
$$

where Return is the return to capital in the business sector.

As Table 11 shows, cointegration is not rejected as the coefficients on the error correction term are all significant and of the right sign. Even though the output gap is a stationary variable, it was

44 It is well known that the two-step procedure is not efficient and may also give biased results with respect to cointegration. However, because of the limited number of observations, it was not possible to estimate a single-equation error correction model for all countries. Even so, we did not succeed in deriving plausible inflow equations for Japan and Germany. For both countries, inflows have been small relative to outflows and seem to suffer from unusually large measurement errors (see Jost (1997)). 
included in (3.4) since removing the cyclical influence helps uncover the underlying determinants. The most striking result is the dominating influence of equity prices and exchange rate movements on outflows. Combined with the fact that, except for the United Kingdom, the coefficients on changes in real effective exchange rates are insignificant and of the "wrong" sign, this result gives strong support to the relative wealth hypothesis. At the same time, it appears that a nominal appreciation deters inflows whereas a high return on capital in the business sector has a stimulatory effect. The influence of long-term interest rates is ambiguous. For the United States, high interest rates seem to reduce outflows and encourage inflows. Conversely, for Germany and Japan, outflows rise in conditions of high interest rates and, for the United Kingdom, inflows decline in response to high interest rates.

Table 11

Determinants of outflows and inflows

Time-series regressions, four countries

\begin{tabular}{|c|c|c|c|c|c|c|}
\hline \multirow[t]{3}{*}{ Determinants } & \multicolumn{4}{|c|}{ Outflows } & \multicolumn{2}{|c|}{ Inflows } \\
\hline & $\begin{array}{l}\text { United } \\
\text { States }\end{array}$ & Japan & Germany & $\begin{array}{l}\text { United } \\
\text { Kingdom }\end{array}$ & United States & $\begin{array}{l}\text { United } \\
\text { Kingdom }\end{array}$ \\
\hline & \multicolumn{6}{|c|}{ Error correction equations } \\
\hline$E c m_{-1}$ & $-1.15(6.6)$ & $-0.53(3.2)$ & $-1.00(4.6)$ & $-0.33(2.7)$ & $-0.64(3.6)$ & $-1.31(7.2)$ \\
\hline Gap & $0.49(4.1)^{1}$ & - & - & $0.09(4.0)$ & $0.16(4.0)^{1}$ & $0.20(1.9)$ \\
\hline Gap $_{-1}$ & $-0.40(3.0)^{1}$ & - & $-0.04(2.3)$ & $-0.12(5.1)$ & - & - \\
\hline$\Delta I r_{-1}$ & $-0.61(2.1)$ & $0.19(3.0)$ & $0.14(4.4)$ & - & $0.27(3.4)$ & - \\
\hline$\Delta \log e_{-1}$ & - & $-0.70(2.2)^{2}$ & - & - & $-1.24(1.8)$ & - \\
\hline$\Delta \log r e_{-1}$ & $-3.00(0.6)^{3}$ & $-0.77(0.9)^{3}$ & $-0.79(1.0)^{3}$ & $1.40(2.0)$ & - & - \\
\hline$\Delta \log (e * e q)$ & - & $0.75(2.5)$ & $0.91(3.4)$ & - & - & - \\
\hline $\mathrm{R}^{2}$ & 0.66 & 0.65 & 0.62 & 0.56 & 0.47 & 0.69 \\
\hline Standard error & 1.33 & 0.25 & 0.15 & 0.24 & 0.40 & 1.38 \\
\hline \multirow[t]{2}{*}{ DW } & 1.85 & 1.82 & 2.27 & 2.25 & 2.20 & 2.26 \\
\hline & \multicolumn{6}{|c|}{ Cointegration equations } \\
\hline Gap & 0.39 & - & 0.03 & 0.09 & 0.10 & 0.22 \\
\hline Ir & -0.17 & 0.15 & 0.08 & 0.14 & 0.48 & -0.19 \\
\hline $\log (e * e q)$ & 1.61 & 1.66 & 1.02 & 1.44 & $-1.92^{4}$ & $-5.50^{4}$ \\
\hline Return & - & - & - & - & 0.71 & 0.19 \\
\hline $\mathrm{R}^{2}$ & 0.44 & 0.98 & 0.97 & 0.83 & 0.92 & 0.25 \\
\hline Standard error & 1.42 & 0.33 & 0.15 & 0.44 & 0.47 & 1.68 \\
\hline DW & 2.16 & 0.90 & 2.06 & 1.03 & 1.46 & 2.50 \\
\hline Period & 1964-97 & $1966-97$ & 1971-97 & 1971-97 & 1966-97 & 1973-97 \\
\hline
\end{tabular}

${ }^{1} \Delta$ Gap. $\quad{ }^{2}$ Bilateral dollar exchange rate. $\quad{ }^{3}$ Not included in final equation. $\quad{ }^{4} \log e$ only.

\section{Effects of FDIs on domestic investment and net exports}

This section presents further time-series estimates for the United States, Japan, Germany and the United Kingdom, using an error correction version of the model in Feldstein (1994) to identify 
possible feedback effects of FDIs on domestic variables. As argued by Janson (1996), long-run saving and investment rates are tied together by the intertemporal budget constraint. Hence, short-run savinginvestment dynamics should, in principle, be modelled using an error correction framework, such as:

$\Delta(I / Y)_{t}=\alpha+\beta \Delta(S / Y)_{t}+\gamma\left[(S / Y)_{t-1}-(I / Y)_{t-1}\right]+\delta(S / Y)_{t-1}+\varepsilon_{t}$

where $\varepsilon$ denotes the disturbance term and $\beta$ measures contemporaneous comovements of domestic saving and investment rates, while $\gamma$ and $\delta$ indicates the nature of the long-run relationship between domestic saving and investment. For $\gamma$ significantly positive and $\delta=0$, the balance of payments is stationary around a long-run value of $-\alpha / \gamma$. When both $\gamma$ and $\delta$ are significantly different from $0, S / Y$ and $I / Y$ are still cointegrated but net exports are non-stationary. One reason for this might be that net outflows lead to a fall in $I / Y$ and a domestic saving surplus while, in an accounting sense, the associated surplus on net exports is offset by net FDI outflows. One way of modelling this would be to follow Feldstein and add FDI flows to equation (4.1) above.

In addition, however, FDI flows could directly influence exports and/or imports as discussed extensively in Section 2. For outflows, the sign of the interaction may also change between the building-up and the production phases of foreign plants. Similarly, depending on whether foreign plants are intended to serve third markets or produce intermediate goods for domestic plants, FDI outflows might interact with imports. All in all, therefore, the number of potential transmission channels and feedback effects goes far beyond the scope of a one-equation framework.

Consequently, our estimates are based on three interrelated error correction equations rather than just one, of which the first is a time-series version of Feldstein's equation:

$\Delta(I / Y)_{t}=\alpha+\lambda e c m_{t-1}+\beta \Delta G a p_{t-i}+\phi \Delta S / Y_{t-i}+\mu \Delta F D I(o) / Y_{t-i}+\pi \Delta F D I(i) / Y_{t-i}+\varepsilon_{t}$, with $i=0 \ldots 2$

and $e c m$ the residual from the cointegration equation:

$I / Y=\alpha^{\prime}+\beta^{\prime} G a p+\phi^{\prime} S / Y+\mu^{\prime} F D I(o) / Y+\pi^{\prime} F D I(i) / Y+\varepsilon^{\prime}$

Similar to the time-series estimate discussed in the previous section, the output gap is included in the cointegration equation as it is highly significant for all four countries and helpful in identifying the long-run trends.

The second and third models form the external counterparts to (4.2) and (4.3). However, since the ratio of net exports to GDP is stationary or nearly stationary in all four countries (Annex Table 4), we imposed parameter restrictions so that the cointegration equations respected the intertemporal budget constraint and allowed only one cointegrating vector:

$$
\begin{aligned}
& E x / Y=\chi^{\prime}+\delta I m / Y+\beta^{\prime} G a p+\varphi^{\prime} F D I(o) / Y+\kappa^{\prime} F D I(i)+\theta^{\prime} \log e+v^{\prime} \\
& I m / Y=\chi+(1 / \delta) E x / Y+\beta G a p+\varphi F D I(o) / Y+\kappa F D I(i)+\theta \log e+v
\end{aligned}
$$


while no restrictions were imposed on the corresponding error correction equations:

$$
\begin{aligned}
& \Delta(E x / Y)_{t}=\varpi^{\prime} e c m_{t-1}+\phi^{\prime} \Delta(\operatorname{Im} / Y)_{t-i}+\lambda^{\prime} G a p_{t-i}+\sigma^{\prime} \Delta(F D I(o) / Y)_{t-i}+\mathrm{l}^{\prime} \Delta\left(F D I(i) / Y_{t-i}+\gamma^{\prime} \Delta \log e_{t-i}+\eta_{t}^{\prime}\right. \\
& \Delta(\operatorname{Im} / Y)_{t}=\bar{\omega}^{\prime} c m_{t-1}+\phi \Delta(E x / Y)_{t-i}+\lambda G a p_{t-i}+\sigma \Delta(F D I(o) / Y)_{t-i}+1 \Delta\left(F D I(i) / Y_{t-i}+\gamma \Delta \log e_{t-i}+\eta_{t}\right.
\end{aligned}
$$

with $i=0 \ldots 2$.

Table 12

\section{Foreign direct investments and total domestic investment}

\begin{tabular}{|c|c|c|c|c|}
\hline \multirow[t]{3}{*}{ Determinants } & \multicolumn{4}{|c|}{ Total domestic investment } \\
\hline & United States & Japan & Germany ${ }^{1}$ & United Kingdom \\
\hline & \multicolumn{4}{|c|}{ Error correction equations } \\
\hline$E_{c m}$ & $-0.21(2.1)$ & $-0.71(4.6)$ & $-0.47(2.8)$ & $-0.38(2.1)$ \\
\hline$\Delta G a p$ & $0.31(4.7)$ & $0.41(3.9)$ & $0.59(6.3)$ & $0.41(4.5)$ \\
\hline$\Delta(S / Y)$ & $0.53(4.2)$ & $0.37(2.1)$ & - & $0.24(1.3)$ \\
\hline$\Delta(F D I(\mathrm{o}) / Y)$ & - & $1.60(1.8)$ & $-0.61(0.8)$ & - \\
\hline$\Delta(F D I(i) / Y)$ & - & - & $1.49(2.0)$ & $0.26(1.6)^{2}$ \\
\hline $\mathrm{R}^{2}$ & 0.84 & 0.62 & 0.68 & 0.72 \\
\hline Standard error & 0.48 & 0.94 & 0.75 & 0.82 \\
\hline \multirow[t]{2}{*}{ DW } & 1.90 & 1.87 & 1.60 & 2.03 \\
\hline & \multicolumn{4}{|c|}{ Cointegration equations } \\
\hline Gap & 0.40 & 0.49 & 0.47 & 0.59 \\
\hline$S / Y$ & 0.62 & 0.88 & 0.26 & 0.37 \\
\hline$F D I(0) / Y$ & -1.08 & -1.32 & -1.72 & -0.41 \\
\hline$F D I(i) / Y$ & 1.08 & - & 2.67 & - \\
\hline $\mathrm{R}^{2}$ & 0.73 & 0.83 & 0.68 & 0.77 \\
\hline Standard error & 0.89 & 1.29 & 1.11 & 1.00 \\
\hline DW & 1.05 & 1.40 & 0.87 & 1.03 \\
\hline Period & 1964-97 & $1970-97$ & 1971-97 & 1971-97 \\
\hline
\end{tabular}

Time-series regressions, four countries

${ }^{1}$ The cointegration equation also includes a slope shift dummy for 1991-97, with a coefficient of 0.09 (3.1). ${ }^{2} \Delta \Delta(F D I(i) / Y)$.

Turning to the results for the saving/investment equation (Table 12), the null hypothesis of no cointegration is rejected in all cases, though in the United States and the United Kingdom at a significance level of only $10 \%$. However, both the long- and short-run saving retention ratios vary significantly, being highest in Japan and lowest in Germany. ${ }^{45}$ The output gap enters both the longand the short-run equations, with coefficients ranging from 0.3 to 0.6. Similar to the findings by Feldstein, FDI outflows tend to reduce domestic investment in all four countries, though in Germany this is more than offset by inflows while in the United States the net effect on domestic investment is zero. The short-run effects are not very well determined, though outflows tend to stimulate investment in Japan while inflows stimulate investment in Germany and the United Kingdom. All in all, it appears

45 To reduce the risk of simultaneity biases, the saving ratios were entered with a one-year lag. 
that both short- and long-run changes in the domestic investment ratios are dominated by cyclical factors and changes in domestic saving, with Japan and the United Kingdom most exposed to the risk of net outflows reducing domestic investment. 46

Before presenting the results for the export and import equations, it is helpful to consider the contributions to the US trade balance of US-owned affiliates abroad and foreign-owned affiliates in the United States. As Table 13 shows, their combined trade balance has weakened considerably as the effect of rapid import growth and relatively slow export growth for foreign affiliates in the United States has been aggravated by the deteriorating trade balance of US-owned manufacturing affiliates. In contrast, exports generated by US-owned service affiliates have expanded significantly. Since the "counter-factuals" are not known, it is difficult to say if US affiliate production has complemented or substituted for US exports although the sharp rise in exports through service affiliates is likely to have benefited total US exports, and is thus suggestive of complementarities. It also appears that inflows are complementary to imports, as the rising trade deficit of foreign-owned affiliates in the United States can mostly be attributed to growing imports.

Table 13

Trade effects of foreign direct investment activities, United States

Trade in goods, in billions of US dollars

\begin{tabular}{|l|rrr|rrr|}
\hline & \multicolumn{3}{|c|}{1984} & \multicolumn{3}{c|}{1994} \\
\cline { 2 - 7 } & Exports & Imports & Balance & Exports & Imports & Balance \\
\hline US affiliates abroad & \multicolumn{7}{|c|}{} & & & & & \\
Manufacturing & 37.4 & 34.4 & 3.0 & 74.6 & 85.8 & -11.2 \\
Wholesale trade & 13.0 & 3.3 & 9.7 & 45.9 & 10.2 & 35.7 \\
Others & 2.3 & 11.6 & -9.3 & 5.0 & 7.6 & -2.6 \\
Total & 52.7 & 49.3 & 3.4 & 125.4 & 103.5 & 21.9 \\
\hline Foreign affiliates in the US & & & & & & \\
Manufacturing & 3.7 & 11.4 & -7.7 & 13.8 & 45.1 & -31.3 \\
Wholesale trade & 22.1 & 57.1 & -35.0 & 35.5 & 109.6 & -74.1 \\
Others & 1.2 & 2.0 & -0.8 & 2.4 & 9.3 & -6.9 \\
Total & 27.1 & 70.5 & -43.4 & 51.7 & 164.1 & -112.4 \\
\hline
\end{tabular}

Source: US Department of Commerce Survey of Current Business.

In estimating equations (4.4) and (4.5), it was necessary to adopt rather wide confidence bands to prevent rejection of the parameter restriction on the export/import terms. However, since the coefficients on the error correction terms were all significant and of the right sign (even when no restrictions were imposed), Table 14 reports the results obtained from the constrained version. As

46 While domestic investment in Germany would benefit from net inflows, the actual contribution of net flows has actually been negative in the 1990s, because inflows have fallen sharply. Conversely, Japan has seen a positive contribution because outflows have fallen. 
might be expected, a positive output gap (or a rise in the output gap) tends to stimulate imports and reduce exports and, in most cases, an appreciation of the exchange rate increases the import/GDP ratio and reduces the export ratio.

Table 14

Foreign direct investments, imports and exports

Time-series regressions, four countries

\begin{tabular}{|c|c|c|c|c|c|c|c|c|}
\hline \multirow[t]{3}{*}{ Determinants } & \multicolumn{4}{|c|}{ Imports } & \multicolumn{4}{|c|}{ Exports } \\
\hline & $\begin{array}{l}\text { United } \\
\text { States }\end{array}$ & Japan & Germany $^{1}$ & $\begin{array}{c}\text { United } \\
\text { Kingdom }\end{array}$ & $\begin{array}{l}\text { United } \\
\text { States }\end{array}$ & Japan & Germany $^{1}$ & $\begin{array}{c}\text { United } \\
\text { Kingdom }\end{array}$ \\
\hline & \multicolumn{8}{|c|}{ Error correction equations } \\
\hline$E_{-1}$ & $-0.36(2.4)$ & $-0.38(3.6)$ & $-0.45(3.1)$ & $-0.58(3.9)$ & $-0.69(4.9)$ & $-0.27(2.7)$ & $-0.34(2.4)$ & $-0.34(3.8)$ \\
\hline$\Delta(E x / Y)^{2}$ & $0.71(4.9)$ & $0.91(9.9)$ & $0.80(7.9)$ & $1.16(8.3)$ & $0.53(4.6)$ & $0.67(9.8)$ & $0.81(7.4)$ & $0.63(9.3)$ \\
\hline Gap & $0.14(3.4)$ & $0.12(2.4)$ & - & $0.26(2.5)$ & $-0.08(2.3)$ & $-0.19(3.3)$ & - & $-0.23(3.2)$ \\
\hline Gap $_{-1}$ & $-0.14(3.4)$ & - & - & $-0.19(1.9)$ & $0.21(7.2)$ & $0.19(3.3)$ & - & $0.17(2.3)$ \\
\hline$\Delta(F D I(\mathrm{o}) / Y)$ & $-0.63(2.0)$ & $0.48(0.9)$ & - & $0.48(1.8)$ & $0.24(1.0)$ & - & - & - \\
\hline$\Delta(F D I(i) / Y)$ & $1.17(3.4)$ & - & - & - & $-0.59(1.9)$ & - & - & - \\
\hline$\Delta \log e$ & - & $-4.68(5.0)$ & - & $-4.08(1.2)$ & - & - & - & - \\
\hline$\Delta \log e_{-1}$ & - & $4.68(5.0)$ & $6.02(1.5)$ & - & - & $-3.61(3.0)$ & - & - \\
\hline $\mathrm{R}^{2}$ & 0.60 & 0.89 & 0.78 & 0.81 & 0.78 & 0.84 & 0.71 & 0.79 \\
\hline Standard error & 0.34 & 0.54 & 0.73 & 0.99 & 0.27 & 0.51 & 0.81 & 0.74 \\
\hline \multirow[t]{2}{*}{ DW } & 2.26 & 1.53 & 1.90 & 1.51 & 1.64 & 2.00 & 1.75 & 1.78 \\
\hline & \multicolumn{8}{|c|}{ Cointegration equations } \\
\hline$E x / Y^{2}$ & 1.43 & 1.00 & 0.93 & 0.83 & 0.70 & 1.00 & 1.07 & 1.20 \\
\hline Gap & 0.24 & 0.12 & 0.34 & 0.22 & -0.16 & - & -0.36 & -0.26 \\
\hline$F D I(\mathrm{o}) / Y$ & -1.02 & - & -3.24 & - & 0.71 & -0.39 & 3.48 & - \\
\hline$F D I(i) / Y$ & 1.29 & - & -2.37 & 0.81 & -0.93 & - & 2.54 & -0.97 \\
\hline $\log e$ & 6.63 & -0.98 & - & - & -4.60 & 1.24 & - & - \\
\hline $\mathrm{R}^{2}$ & 0.62 & 0.76 & 0.81 & 0.63 & 0.95 & 0.11 & 0.78 & 0.34 \\
\hline Standard error & 0.67 & 1.19 & 1.19 & 1.49 & 0.48 & 1.14 & 1.24 & 1.75 \\
\hline DW & 0.97 & 0.73 & 1.26 & 0.91 & 0.97 & 0.76 & 1.26 & 0.90 \\
\hline Period & 1964-97 & 1970-97 & 1972-97 & 1971-97 & 1964-97 & 1970-97 & 1972-97 & 1971-97 \\
\hline
\end{tabular}

${ }^{1}$ The cointegration equations also include intercept shift dummies for the period 1991-97, with the following values for respectively the import and export equation: -3.24 (3.9) and 3.47 (5.2). ${ }^{2}$ For the export equations respectively $\Delta(\operatorname{Im} / Y)$ and $\operatorname{Im} / Y$.

With regard to the effect of FDI flows, outflows seem to complement exports for the United States, Japan and, in particular, Germany, whereas no effect was found for the United Kingdom. Contrary to most results in the literature, outflows reduce imports in the United States and Germany while, for Japan and the United Kingdom, there is a positive, albeit only transitory, effect. Conversely, inflows tend to stimulate imports, even though only temporarily in Japan. More surprisingly, inflows also seem to be negatively correlated with exports for the United States and the United Kingdom while no effects were found for Japan. For Germany, inflows are positively 
correlated with both exports and imports, suggesting that foreign firms tend to use Germany as a production and distribution centre for sales in the European region.

Despite some open issues and results that are hard to explain, the estimates in Table 14 are largely in line with the literature and enable us to assess some of the indirect effects of FDI activities on domestic output and employment. First, outflows tend to degress domestic investment though in some cases this may be offset by inflows. Second, for the United States and Germany, there is clear evidence that outflows complement rather than substitute for exports. For the United Kingdom, outflows seem to be neutral with respect to exports while substitution dominates for Japan. Third, inflows tend to raise imports, probably because foreign-owned affiliates buy intermediate goods from parent companies. However, as found for Germany, inflow-induced imports may also reflect the setting-up of plants aimed at serving a whole region and thus also stimulate exports. 


\section{Summary and conclusions}

The purpose of this paper was to look for evidence regarding a possible relationship between foreign direct investment and employment, in particular between outflows and employment in the source countries. From the empirical estimates presented in Sections 3 and 4, it is tempting to conclude that very little has been uncovered and that the paper has left more open issues than provided convincing answers. Yet, a few points are worth highlighting in this concluding section.

It is important to avoid "getting carried away" by high growth rates of FDIs in certain periods. FDI flows are procyclical and quite volatile and high rates of growth often reflect low initial levels. Indeed, when measured in relation to domestic investment or total GDP, outflows and inflows have remained rather low and for many countries far below ratios seen in the 1970s and during the first decade of this century.

Fears that jobs are being destroyed in the industrial countries when multinational enterprises invest in low-wage countries are only in part supported by the evidence. Our empirical estimates suggest that domestic investment tends to decline in response to outflows, although it should be recalled that FDI activities are still dominated by flows between the industrial countries so that net outflows to emerging market countries are rather small. We also find that high labour costs encourage outflows and discourage inflows and that such effects can be reinforced by exchange rate movements. However, the principal determinants of FDI flows seem to be prior trade patterns, IT-related investment and output, and the scope for cross-border mergers and acquisitions. The distribution of FDIs towards services also suggests that a large proportion of foreign investment is undertaken with the purpose of expanding sales and improving the distribution of exports produced in the source countries. Indeed, we find clear evidence that outflows complement rather than substitute for exports and thus help to protect rather than destroy jobs.

While we are merely stating the obvious when referring to the profound influence of globalisation and technological progress on recent developments, it is probably more relevant to FDI activities than to most other areas of recent change. In particular, by allowing firms to redistribute their production and employment according to relative prices, lower communication costs have fundamentally changed the motives for undertaking investment and starting production in other countries. In contrast to earlier periods, where the global output distribution of large multinationals reflected a horizontal structure, the more recent growth of FDIs is associated with a vertical production structure. This in turn implies that the scope for interaction and feedbacks between parents and affiliates is vastly expanded and that even if affiliate production does not affect parents' domestic 
employment, it can influence the skill composition of their labour demand. Moreover, within a vertical production structure it is important to take account of third-country effects. ${ }^{47}$

Turning to open issues and future research, one area that has been covered only superficially in this study is the influence of corporate financial structures on the size and composition of FDIs and, not least, on the distribution between source and host-country sources of finance when expanding capital abroad. US data imply that the capital stocks controlled by US multinationals are two to three times the outward stocks. Should similarly high ratios hold for other countries, whatever evidence is found with respect to interactions between FDIs and source-country employment would provide only a partial answer. The influence of financial asset prices also needs to be taken into account and far more carefully than we have done in this study. This is particularly important in view of the liberalisation and deregulation of financial markets and the associated growing importance of cross-border mergers and acquisitons; processes that are still evolving and still have far to go. Along the same lines, it would be useful to have more information on corporate tax structures, especially since differences across countries, albeit narrowing, are likely to remain for a considerable period. However, based on the evidence covered in this paper, we are not very optimistic that this is an area where quick progress is to be expected. ${ }^{48}$

Although much work has already been done on the influence of exchange rates and labour costs, it is still not entirely clear whether exchange rate movements affect FDIs through relative wealth or relative cost effects. Moreover, the evidence on the influence of exchange rate volatility is not very conclusive. In this respect, new empirical work might be particularly relevant to policymakers in countries that are contemplating moving to a different exchange rate regime.

Unfortunately, further and more conclusive evidence on possible relationships between FDIs and source-country output and employment could be seriously hampered by the lack of reliable and comparable data.49 Long and consistent macro-series on employment in host countries are available for only a few countries and micro-data on the activities of multinationals and their affiliates are even scarcer. Another problem is the lack of consistency and comparability of the measures and definitions used in measuring FDI flows and stocks. In particular, a more comparable and comprehensive reporting of retained earnings and intra-firm debt as sources of finance is needed. Several countries have recently adopted more comprehensive definitions. Unfortunately, the lack of "backdated" series could complicate time-series analyses for several years.

47 For instance, even if output by affiliates in country $b$ does not affect exports from the source country $a$ to country $b, a$ 's exports to country $c$ might decline because that market is served by affiliates in $b$.

48 Corporate tax structures not only differ with respect to average and marginal rates on net earnings; rates also differ depending on the source of financing and the location of FDIs.

49 The United States and Sweden are major exceptions. 


\section{Annexes}

\section{Note on outsourcing}

One recent development that we have so far ignored is outsourcing, which is often mentioned as potentially affecting employment and wage structures in the industrial countries as much as imports, and FDI activities. Similarly to foreign trade, outsourcing contributes to relative factor price equalisation but (Slaughter (1995)) it differs from foreign trade in that it mainly operates within rather than between industries. As noted by Feenstra and Hanson (1996), outsourcing is similar to FDIs in that it is based on a fragmentation of the production process into discrete activities distributed across countries. However, outsourcing differs from outflows in that it does not involve the construction or acquisition of a foreign affiliate.

Probably because of data limitations, there are few studies of the effects of outsourcing. They are mostly confined to US manufacturing but the empirical results differ significantly, depending on the definitions and methodologies applied. Feenstra and Hanson measure outsourcing by imports of parts of components and contract work done by others, and when including changes in the share of outsourcing in total materials used in an equation for changes in the wage share of non-production workers, they find that as much as one-third to one-half of the widening wage distribution can be attributed to outsourcing. However, their methodology seems to exaggerate the impact. Thus, when changes in import penetration replace outsourcing as the explanatory variable, their estimate implies a contribution to wage dispersions, which is significantly larger than consensus estimates. A related study is Campa and Goldberg (1997) who include imported input shares in measuring the external orientation in manufacturing. Their estimates for US manufacturing are largely in line with those shown by Feenstra and Hanson. However, what also appears from Table 12 is that outsourcing has gone furthest in the United Kingdom and Canada and increased the most in the United States. In Japan, despite the impression of major structural changes in foreign trade, the proportion of imported inputs has actually fallen. 


\section{Annex tables}

Table A1

Imported input shares in manufacturing

\begin{tabular}{|l|c|c|c|}
\hline & $\mathbf{1 9 7 4 - 7 5}$ & $\mathbf{1 9 8 4 - 8 5}$ & $\mathbf{1 9 9 4 - 9 5}$ \\
\hline United States & 4.1 & 6.2 & 8.2 \\
Japan & 8.2 & 7.3 & 4.1 \\
United Kingdom & 13.4 & 19.0 & 21.7 \\
Canada & 15.9 & 14.4 & 20.2 \\
\hline
\end{tabular}

Source: Campa and Goldberg (1997).

Table A2

Compensation and output per employee in US foreign affiliates 1996 data

\begin{tabular}{|c|c|c|c|c|}
\hline & $\begin{array}{l}\text { Compensation } \\
\text { per employee }\end{array}$ & $\begin{array}{c}\text { Output per } \\
\text { employee }\end{array}$ & Share of FDIs & $\begin{array}{l}\text { Services/total } \\
\text { employment }\end{array}$ \\
\hline & \multicolumn{2}{|c|}{ in thousands of US\$ } & \multicolumn{2}{|c|}{ in percentages } \\
\hline Switzerland & 82.5 & 190.1 & 2.4 & 61.9 \\
\hline Japan & 77.1 & 146.3 & 6.2 & 48.0 \\
\hline Belgium & 61.2 & 134.8 & 3.8 & 34.3 \\
\hline Germany & 57.5 & 110.1 & 15.8 & 27.2 \\
\hline France & 50.8 & 94.1 & 9.9 & 39.8 \\
\hline Netherlands & 48.6 & 121.0 & 4.7 & 44.5 \\
\hline United Kingdom & 37.2 & 97.3 & 21.3 & 46.0 \\
\hline Australia & 33.5 & 79.3 & 4.4 & 53.3 \\
\hline Canada & 32.8 & 65.1 & 13.8 & 54.5 \\
\hline Argentina & 29.4 & 79.1 & 1.6 & 33.4 \\
\hline Korea & 28.2 & 73.3 & 0.7 & 42.2 \\
\hline Hong Kong & 27.6 & 65.0 & 1.6 & 45.1 \\
\hline Brazil & 27.3 & 73.7 & 5.4 & 15.9 \\
\hline Singapore & 25.9 & 71.0 & 1.8 & 23.9 \\
\hline Taiwan & 22.0 & 46.2 & 0.8 & 41.4 \\
\hline Mexico & 9.6 & 20.5 & 2.7 & 12.4 \\
\hline Thailand & 9.3 & 42.2 & 0.9 & 12.8 \\
\hline Malaysia & 9.1 & 34.7 & 1.2 & 5.8 \\
\hline Philippines & 8.4 & 32.8 & 0.6 & 16.6 \\
\hline China & 6.1 & 19.0 & 0.6 & 12.3 \\
\hline Total & 35.9 & 79.5 & 100.0 & 36.2 \\
\hline Manufacturing & 32.9 & 66.1 & 49.9 & - \\
\hline Memorandum items: & & & & \\
\hline US parents & 44.9 & 78.1 & - & 49.8 \\
\hline Manufacturing & 51.8 & 84.1 & - & - \\
\hline US total economy & 35.9 & 59.8 & - & 81.8 \\
\hline Manufacturing & 45.2 & 72.3 & - & - \\
\hline
\end{tabular}

Note: Bilateral correlations: $R w, y=0.97 ; R y, s=0.67$; and $R w, s=0.68$, with $w=$ compensation per employee, $y=$ output per employee and $s=$ employment share, services.

Source: US Department of Commerce Survey of Current Business. 
Table A3a

Determinants of FDI outflows and inflows

Pooled estimates, cumulated flows

\begin{tabular}{|l|c|c||c|c|}
\hline \multirow{2}{*}{ Determinants } & \multicolumn{2}{|c||}{ Outflows (equation 3.1) } & \multicolumn{2}{c|}{ Inflows (equation 3.2) } \\
\cline { 2 - 5 } & EU countries & Non-EU countries & EU countries & Non-EU countries \\
\hline$\Delta Y$ & $0.30(4,7)$ & $0.47(4.0)$ & - & - \\
$I / Y$ & $0.14(3.5)$ & $0.09(1.2)$ & $0.15(2.8)$ & - \\
$\Delta I t$ & $1.22(4.6)$ & $1.76(3.6)$ & $0.64(2.5)$ & $0.73(2.0)$ \\
$E x / Y \quad(\mathrm{Im} / Y)$ & $0.13(2.4)$ & $0.18(1.6)$ & $0.14(2.5)$ & $0.24(2.1)$ \\
$\log \left(L^{*} T u / C\right)$ & $0.83(9.6)$ & $1.03(6.2)$ & $0.30(3.1)$ & $0.18(1.2)$ \\
$I r$ & - & - & $-0.57(5.3)$ & $-0.66(5.0)$ \\
$\Delta e$ & $0.08(1.6)$ & $0.21(3.2)$ & $-0.42(3.5)$ & $-0.52(4.0)$ \\
$\log L c$ & $1.44(3.2)$ & - & $-0.65(1.6)$ & $-1.02(1.4)$ \\
$E U$ & $2.03(6.1)$ & $0.34(0.6)$ & $3.58(6.7)$ & $2.47(4.6)$ \\
$\mathrm{R}^{2}$ & 0.68 & 0.68 & 0.70 & 0.59 \\
Standard error & 1.4 & 1.7 & 1.2 & 1.7 \\
\hline Countries & 14 & 7 & 12 & 7 \\
Observations & 241 & 92 & 205 & 99 \\
\hline
\end{tabular}

Table A3b

Determinants of FDI outward and inward stocks

Pooled estimates, end period stocks

\begin{tabular}{|l|c|c||c|c|}
\hline \multirow{2}{*}{ Determinants } & \multicolumn{2}{|c||}{ Outward stocks (equation 3.1) } & \multicolumn{2}{c|}{ Inward stocks (equation 3.2) } \\
\cline { 2 - 5 } & EU countries & Non-EU countries & EU countries & Non-EU countries \\
\hline$\Delta Y$ & $0.32(4.5)$ & $0.45(4.4)$ & - & - \\
$I / Y$ & $0.11(2.5)$ & $0.09(1.2)$ & $0.14(2.5)$ & $0.03(0.4)$ \\
$\Delta I t$ & $1.67(5.4)$ & $1.74(4.0)$ & $0.73(2.6)$ & $0.35(0.9)$ \\
$E x / Y \quad(I m / Y)$ & $0.27(3.2)$ & $0.13(1.6)$ & $0.15(2.0)$ & $0.21(2.4)$ \\
$\log \left(L^{*} T u / C\right)$ & $0.66(6.1)$ & $1.05(7.2)$ & $0.28(2.6)$ & $0.32(2.1)$ \\
$I r$ & - & - & $-0.56(4.8)$ & $-0.57(3.5)$ \\
$\Delta e$ & $0.13(2.4)$ & $0.22(2.7)$ & $-0.40(3.1)$ & $-0.34(1.9)$ \\
Log $L c$ & $0.56(1.1)$ & $0.47(0.6)$ & $-0.73(1.6)$ & $-1.43(2.4)$ \\
$E U$ & $1.12(2.9)$ & $0.78(1.6)$ & $3.33(5.7)$ & $2.12(2.6)$ \\
$\mathrm{R}^{2}$ & 0.70 & 0.74 & 0.70 & 0.62 \\
Standard error & 1.3 & 1.4 & 1.2 & 1.4 \\
\hline Countries & 8 & 5 & 8 & 6 \\
Observations & 138 & 85 & 147 & 108 \\
\hline
\end{tabular}


Table A4

Integration tests

Figures indicate t-ratios of $\beta^{1}$

\begin{tabular}{|c|c|c|c|c|c|c|c|c|}
\hline \multirow[t]{2}{*}{ Variables } & \multicolumn{2}{|c|}{ United States } & \multicolumn{2}{|c|}{ Germany } & \multicolumn{2}{|c|}{ Japan } & \multicolumn{2}{|c|}{ United Kingdom } \\
\hline & Level & $\begin{array}{c}\text { First } \\
\text { difference }\end{array}$ & Level & $\begin{array}{c}\text { First } \\
\text { difference }\end{array}$ & Level & $\begin{array}{c}\text { First } \\
\text { difference }\end{array}$ & Level & $\begin{array}{c}\text { First } \\
\text { difference }\end{array}$ \\
\hline$E x / Y$ & -0.8 & -4.9 & -0.3 & -4.7 & -2.1 & -5.0 & -1.0 & -5.0 \\
\hline $\operatorname{Im} / Y$ & -0.2 & -4.7 & -1.7 & -4.5 & -2.3 & -4.9 & -1.4 & -4.9 \\
\hline Bop $/ Y$ & $-2.5^{2}$ & -2.7 & -2.9 & -4.9 & -3.0 & -4.8 & -3.3 & -5.0 \\
\hline$F D I(\mathrm{o}) / Y$ & -2.0 & -4.5 & -1.3 & -4.4 & -2.5 & -2.3 & -3.9 & -2.3 \\
\hline$F D I(i) / Y$ & -1.4 & -4.4 & -2.5 & -4.3 & - & - & -4.8 & - \\
\hline$I / Y$ & -2.1 & -4.6 & -1.9 & -4.8 & -1.9 & -4.2 & -2.7 & -10.2 \\
\hline$S / Y$ & -1.0 & -2.1 & -1.6 & -4.1 & -1.7 & -4.0 & -1.6 & -4.0 \\
\hline re & -2.2 & -3.2 & -1.4 & -4.2 & -0.5 & -3.3 & -2.4 & -3.1 \\
\hline Gap & -4.8 & - & -4.1 & - & -3.0 & - & -3.8 & - \\
\hline
\end{tabular}

${ }^{1}$ Obtained by estimating the following equation in respectively level and first-difference form: $\Delta y=\alpha+\beta y_{-1}+\delta_{i} \Delta y_{-i}$, with $i=1 \ldots . .4 . \quad{ }^{2}$ Also includes a linear trend. 


\section{Bibliography}

Agarwal, J.P. (1997): "European Integration and German FDI: Implications for Domestic Investment and Central European Economies", National Institute Economic Review, April, pp. 100-11.

Altschuler, R., H. Grubert and T.S. Newlon (1998): "Has US investment abroad become more sensitive to tax rates?" NBER Working Paper, No. 6383.

Barrell, R. and N. Pain (1997): "The Growth of Foreign Direct Investment in Europe", National Institute Economic Review, April, pp. 63-75.

Bayoumi, T., L. Bartolini and M. Klein (1996): "Foreign Direct Investment and the Exchange Rate", in IMF Occasional Paper, No. 145, pp. 47-58.

Bayoumi, T. and G. Lipworth (1997): "Japanese Foreign Direct Investment and Regional Trade", IMF Working Paper, No. 97/103.

Blomström, M. and A. Kokko (1997): "Regional Integration and Foreign Direct Investment", CEPR Discussion Paper, No. 1659.

Blomström, M., G. Fors and R. Lipsey (1997): "Foreign Direct Investment and Employment: Home Country Experience in the United States and Sweden”, NBER Working Paper, No. 6205.

Blomström, M., R. Lipsey and K. Kulchycky (1988): "US and Swedish direct investment and exports", in R. Baldwin (ed.) Trade Policy Issues and Empirical Results, Chicago University Press, pp. 259-97.

Brainard, S. and D. Riker (1997a): “Are US Multinationals exporting US jobs?" NBER Working Paper, No. 5958.

Brainard, S. and D. Riker (1997b): "US Multinationals and competition from low-wage countries", NBER Working Paper, No. 5959.

Campa, J. and L. Goldberg (1997): "The evolving external orientation of manufacturing: a profile of four countries", Federal Reserve Bank of New York, Economic Policy Review, July, pp. 53-81.

Caves, R. (1989): "Exchange Rate Movements and Foreign Direct Investment in the United States", in D. Audretsch and M. Claudon (eds.) The Internationalisation of US Markets, New York University Press, pp. 199-228.

Culem, C. (1988): "The locational determinants of direct investments among industrial countries", European Economic Review, pp. 885-904.

Cushman, D. (1985): "Real exchange rate risk: expectations and the level of direct investment", Review of Economics and Statistics, pp. 297-308.

Devereux, M.P. (1996): "Investment, saving and taxation in an open economy", Oxford Review of Economic Policy, pp. 90-108.

Dewenter, K.L. (1995): “Do Exchange Rate Changes Drive Foreign Direct Investment?" Journal of Business, pp. 405-33.

Dunning, J. (1958): American Investment in British Manufacturing, George Allen and Unwin, London. 
Döhrn, R. (1997): "Bestimmungsgründe von Umfang und Entwicklung der Auslandsaktivitäten deutscher Unternehmen”, Lecture Notes, RWI Institute, Essen.

European Commission (1998): "Foreign direct investment", The Single Market Review, Subseries IV, European Communities, Luxembourg.

Feldstein, M. (1994): "The Effects of Outbound Foreign Direct Investment on the Domestic Capital Stock", NBER Working Paper, No. 4668.

Feldstein, M. and C. Horioka (1980): "Domestic saving and international capital flows", Economic Journal, pp. 314-29.

Fontagnë, L. and M. Pajot (1997): "How foreign direct investment affects international trade and competitiveness: an empirical assessment", Centre d'Études Prospectives et d'Informations Internationales, Document de Travail, No. 97-17.

Froot, K. and J. Stein (1991): "Exchange Rates and Foreign Direct Investment: An Imperfect Capital Markets Approach", Quarterly Journal of Economics, pp. 1191-217.

Goldberg, L.S. and M.W. Klein (1998): "Foreign direct investment, trade and real exchange rate linkages in South East Asia and Latin America”, NBER Working Paper, No. 6344.

Goldberg, L.S. and C.D. Kolstad (1995): "Foreign direct investment, exchange rate variability and demand uncertainty", International Economic Review, pp. 855-73.

Graham, E. (1995): "Foreign Direct Investment in the World Economy", IMF Working Paper, No. 95/59.

Harris, R. and D. Ravenscraft (1991): "The Role of Acquisitions in Foreign Direct Investment: Evidence from the US Stock Market", Journal of Finance, pp. 825-44.

Hatzius, J. (1997a): "Foreign direct investment, capital formation and labour costs: evidence from Britain and Germany", Centre for Economic Performance Discussion Paper, No. 336.

Hatzius, J. (1997b): "Domestic jobs and foreign wages: labour demand in Swedish multinationals", Centre for Economic Performance Discussion Paper, No. 337.

Hubert, E., N. Pain and R. Barrell (1997): "Innovation and the regional and industrial pattern of German foreign direct investment", Investment, Innovation and the Diffusion of Technology in Europe, NIESR Conference, February.

Hufbauer, G., D. Lakdawalla and A. Malani (1994): "Determinants of Foreign Direct Investment and its Connection to Trade", UNCTAD Review, pp. 39-51.

Hymer, S. (1959): The International Operations of National Firms, MIT Press.

Janson, W.J. (1996): "Estimating saving-investment correlations: evidence for OECD countries based on an error correction model", Journal of International Money and Finance, pp. 749-81.

Jost, T. (1997): "Direct Investment and Germany as a Business Location", Discussion Paper, No. 2/97, Deutsche Bundesbank.

Klein, M. and E. Rosengren (1994): "The real exchange rate and foreign direct investment in the United States", Journal of International Economics, pp. 373-89. 
Klodt, H. and R. Maurer (1996): "Internationale Direktinvestitionen: Determinanten und Konsequenzen für den Standort Deutschland", Kieler Diskussionsbeiträge, No. 284.

Kojima, K. (1985): "Japanese and American direct investment in Asia: a comparative analysis", Hitotsubashi Journal of Economics, June.

Kozul-Wright, R. and R. Rowthorn (1998): "Spoilt for choice? Multinational corporations and the geography of international production", Oxford Review of Economic Policy, pp. 74-92.

Kravis, R. and R. Lipsey (1988): "The effect of multinational firms foreign operations on domestic employment”, NBER Working Paper, No. 2760.

Krugman, P. (1995): "Growing World Trade: Causes and Consequences", Brookings Papers on Economic Activity, pp. 327-77.

Leibfritz, W., J. Thornton and A. Bibbee (1997): "Taxation and Economic Performance", OECD Working Papers, No. 176.

Lipsey, R. (1994): "Outward Direct Investment and the US Economy", NBER Working Paper, No. 691.

Lipsey, R. and M. Weiss (1981): "Foreign production and exports in Manufacturing industries", Review of Economics and Statistics, pp. 488-94.

Lipsey, R. and M. Weiss (1984): "Foreign production and exports of individual firms", Review of Economics and Statistics, pp. 304-8.

Lizondo, S. (1991): “Foreign Direct Investment”, IMF Occasional Paper, No. 77, pp. 68-82.

Marcusen, J.R. (1995): "The boundaries of multinational enterprises and the theory of international trade", Journal of Economic Perspectives, pp. 169-89.

Marcusen, J.R. (1997): “Trade versus investment liberalisation”, NBER Working Paper, No. 6231.

Martin, C. and F. Velázquez (1997): "The Determining Factors of Foreign Direct Investment in Spain and the Rest of the OECD: Lessons for the CEECS", CEPR Discussion Paper, No. 1637.

Mundell, R. (1957): "International Trade and Factor Mobility", American Economic Review, pp. 321-35.

OECD: International Direct Investment Statistics, several issues.

Oman, C. (1994): Globalisation and Regionalisation: The Challenge for Developing Countries, OECD, Paris.

Ostry, S. (1997): “A New Regime for Foreign Direct Investment”, Group of Thirty, Occasional Paper, No. 53.

Pain, N. and K. Wakelin (1996): "Foreign direct investment and export performance", Conference, European Association for Research in Industrial Countries, Vienna.

Pain, N. and M. Lansbury (1997): "Regional Economic Integration and Foreign Direct Investment: The Case of German Investment in Europe", National Institute Economic Review, April, pp. 87-99. 
Parisotto, A. (1995): "Recent Trends in Employment in Transnational Corporations", in Foreign Direct Investment, Trade and Employment, OECD, Paris, pp. 67-76.

Pfaffermayer, M. (1994): "Foreign Direct Investment and Exports: A Time-series Approach", Applied Economics, pp. 337-51.

Ruane, F. and H. Görg (1997): "The Impact of Foreign Direct Investment on Sectoral Adjustment in the Irish Economy", National Institute Economic Review, April, pp. 76-86.

Slaughter, M. (1995): "Multinational Corporations, Outsourcing and American Wage Diversion", NBER Working Paper, No. 5253.

Stevens, V. and R. Lipsey (1992): "Interactions between domestic and foreign investment", Journal of International Money and Finance, pp. 40-62.

Stockman, A. and P. Vlaar (1996): "Volatility, international trade and capital flows", Netherlands Bank, Reprint Series, No. 453.

Swedenborg, B. (1985): "Sweden", in J. Dunning (ed.) Multinational Enterprises, Economic Structure and International Competitiveness, pp. 217-48.

Svensson, R. (1996): "Effects of Overseas Production on Home Country Exports: Evidence based on Swedish Multinationals", Weltwirtschaftliches Archiv, pp. 304-29.

UNCTAD (1997): World Investment Report.

Vernon, R. (1966): "International Trade and International Investment in the Product Cycle", Quarterly Journal of Economics, pp. 190-207.

Wells, L. (1992): "Conflict or Indifference: US Multinationals in a World of Regional Trading Blocs", OECD Technical Paper, No. 57.

Wheeler, D. and A. Mody (1992): "International investment location", Journal of International Economics, pp. 57-76.

WTO (1996a): Trade and Foreign Direct Investment, A New Report by the WTO, October.

WTO (1996b): Annual Report.

Zhao, L. (1998): "The impact of foreign direct investment on wages and employment", Oxford Economic Papers, pp. 284-301. 



\section{Recent BIS Working Papers}

No.

45

August 1997

46

September 1997

47

September 1997

48

September 1997

49

September 1997

50

November 1997

51

November 1997

52

January 1998

53

March 1998

54

June 1998

55

June 1998

56

June 1998

57

July 1998

58

November 1998

59

November 1998

60

November 1998
Title

A multi-country comparison of the linkages between inflation and exchange rate competitiveness

Global asset allocation in fixed income markets

Financial asset prices and monetary policy: theory and evidence

Some multi-country evidence on the effects of real exchange rates on output

Why does the yield curve predict economic activity? Dissecting the evidence for Germany and the United States

The euro and the dollar

Forecast errors and financial developments

Inflation and disinflation in Iceland

Exchange rate regimes and inflation and output in Sub-Saharan countries

The coming transformation of continental European banking?

Spread overreaction in international bond markets

Commercial banks in the securities business: a review

One-step prediction of financial time-series

The importance of bank seniority for relationship lending

Portfolio selection using fuzzy decision theory

Output gap uncertainty: does it matter for the Taylor rule?
Author

Steven B. Kamin

Srichander

Ramaswamy

Frank Smets

Steven B. Kamin and Marc Klau

Frank Smets and Kostas Tsatsaronis

Robert N. McCauley

Palle S. Andersen

Palle S. Andersen and Már Guðmundsson

Marc Klau

William R. White

Gregory D. Sutton

João A. C. Santos

Srichander

Ramaswamy

Stanley D. Longhofer and João A. C. Santos

Srichander

Ramaswamy

Frank Smets 